\title{
Pomelo fruit wastes are potentially valuable antioxidants, anti-inflammatories, antihypertensives, and antihyperglycemics
}

\author{
Li-Yun Lin $^{1} \cdot$ Chi-Yun Huang ${ }^{1} \cdot$ Kuan-Chou Chen ${ }^{2,3}$ [D $\cdot$ Robert Y. Peng ${ }^{4,5}$
}

Received: 25 February 2020 / Revised: 2 December 2020 / Accepted: 4 December 2020 / Published online: 16 February 2021

(c) The Author(s) 2021

\begin{abstract}
Grapefruit (G) parts contain abundant phenolic acids and flavonoids (PPNs and FLVs). The wastes created from exocarps, mesocarps (G wastes, GW) and waste blanching water (WBW) lead to a considerable loss of PPNs and FLVs. Here, we assessed Buntan (CB), Buntan Hayata (CBH), and Peiyu (CP) cultivars and observed considerable amounts of PPNs and FLVs. The ethanolic extracts of GW (GWE) and WBW contained gallic acid, protocatechuic acid, chlorogenic acid, caffeic acid, ferulic acid, coumaric acid, naringin, hesperidin, diosmin, quercetin, hesperetin, nobiletin, and tangeretin (GWC). GWE has previously been reported to be a relatively active antioxidant, anti-inflammatory (based on the expression of TNF- $\alpha$ in Raw264.7 cells), antihypertensive, and anti-hyperglycemic compound. The $\mathrm{IC}_{50}$ values for antihyperglycemic activity with WBW for $\alpha$-amylase were as follows: $\mathrm{CB}(27.96 \pm 0.03 \mathrm{mg} / \mathrm{mL})<\mathrm{CP}(28.13 \pm 0.19 \mathrm{mg} / \mathrm{mL})<\mathrm{CBH}(41.60 \pm 0.16 \mathrm{mg} /$ $\mathrm{mL})$, and those for $\alpha$-glucosidase were CB $(1.80 \pm 0.03 \mathrm{mg} / \mathrm{mL})<\mathrm{CP}(2.97 \pm 0.29 \mathrm{mg} / \mathrm{mL})<\mathrm{CBH}(9.10 \pm 0.51 \mathrm{mg} / \mathrm{mL})$. GWC upregulated Glut4 in HepG2 cells, as well as the insulin secretion capability, and intracellular levels in RIN-m5F cells, and it downregulated DPP4 in HepG2 cells. The $\mathrm{IC}_{50}$ values for the angiotensin-converting enzyme activity were: CBP $(5.10 \pm 0.02 \mathrm{mg} / \mathrm{mL})<\mathrm{CB}(7.24 \pm 0.65 \mathrm{mg} / \mathrm{mL})<\mathrm{CP}(8.60 \pm 2.03 \mathrm{mg} / \mathrm{mL})$. Our results indicate that PPNs and FLVs present in GW are worth reclaiming.
\end{abstract}

Keywords $\alpha$-Amylase $\cdot \alpha$-Glucosidase $\cdot$ Angiotensin-I converting enzyme $\cdot$ Buntan $\cdot$ Citrus grandis $\cdot$ Insulin $\cdot$ Peiyu $\cdot$ Polyphenolics and flavonoids

\section{Introduction}

Communicated by Sanghyun Lee.

Kuan-Chou Chen

kuanchou@tmu.edu.tw

1 Department of Food and Applied Technology, Hungkuang University, No. 1018, Sec. 6, Taiwan Boulevard, Shalu District, Taichung City 43302, Taiwan

2 TMU-Research Center of Urology and Kidney, Taipei Medical University, and Graduate Institute of Clinical Medicine, College of Medicine, Taipei Medical University, No. 250, Wu-Xin, St. Taipei 110, Taiwan

3 Department of Urology, Taipei Medical University-Shuang Ho Hospital, 250, Wu-Xin St., Xin-Yi District, Taipei 110, Taiwan

4 School of Medicine and Nursing, Hungkuang University, No. 1018, Sec. 6, Taiwan Boulevard, Shalu District, Taichung City 43302, Taiwan

5 Research Institute of Medical Sciences, Taipei Medical University, 250, Wu-Xin St., Xin-Yi District, Taipei 110, Taiwan
The pomelo, also called Citrus grandis (L.) Osbeck or Citrus maxima (Burm.) Merr., is the largest citrus fruit of the Rutaceae family and is commonly consumed in Taiwan. C. grandis contains abundant nutrients, including vitamins, minerals, and valuable organic compounds. Usually, $C$. grandis is consumed as a whole fruit or in drinks such as juice. In Taiwan, pomelo cultivation covered a total area of 5089 ha in 2015; Taiwan produces 72,724 tons of pomelo yearly, comprising over 20 native cultivars as well as new imported species. The Buntan grapefruit (C. grandis [L.] Osbeck cv. Buntan) and $C$. grandis (L.) Osbeck cv. Peiyu are the two most common cultivars.

The flavedo and albedo of $C$. grandis pomelos are rich sources of antioxidants (Lü et al. 2016). Naringenin, hesperetin, diosmin, and gallic acid are the predominant phenolics present in the flavedo, whereas hesperetin, diosmin, rutin, chlorogenic acid, and GA are the most abundant in the albedo (Lü et al. 2016). 
An International Diabetes Federation cohort report (2017) indicated that 350 million individuals had diabetes mellitus, and this number was expected to reach nearly 700 million by 2045 (IDF 2017). Currently, antidiabetic drugs and therapies are being increasingly commercialized (Nicholson and Hall 2011; Deacon 2011), such as antagonists of pancreatic $\alpha$-amylase and $\alpha$-glucosidase (Oboh et al. 2016; Schnell et al. 2016), glucose transporter 4 (Glut4) trafficking accelerator (Huang et al. 2005), and dipeptidyl peptidase 4 (DPP4) inhibitors (Dicker 2011; Drucker and Nauck 2006). Preparations such as acarbose and miglitol delay the elevation of postprandial glucose by hindering the digestion of carbohydrates and suppressing its absorbability, which results in a delayed and reduced elevation of the postprandial glucose level (Iqbal et al. 2013; Oboh et al. 2016; Schnell et al. 2016). However, adverse effects have been occasionally reported, including enteric gas tension and diarrhea, and $\alpha$-glucosidase inhibitors may cause irritable bowel syndrome and are incompatible with severe renal and hepatic dysfunction (Oboh et al. 2016).

The insulin-dependent translocation of Glut4 from intracellular storage sites to the plasma membrane plays a key role in the dynamic regulation of glucose homeostasis (Huang et al. 2005; Du et al. 2017). This process requires the trafficking of Glut4-containing vesicles toward the cell periphery, docking at exocytic sites, and plasma membrane fusion (Huang et al. 2005). Phospholipase D1 (PLD1), present in Glut4-containing vesicles, is activated by insulin signaling and traffics with Glut4 toward exocytic sites to facilitate glucose uptake (Huang et al. 2005).

DPP4 (also called CD26; $110 \mathrm{kDa}$; the target of the gliptins), previously characterized in immune cells, has essential metabolic functions, which are not fully understood yet (Zilleßen et al. 2016). DPP4 degrades incretin peptides (e.g., GLP1) and is widely known for its regulatory effect on glucose metabolism (Drucker and Nauck 2006). Gliptins, a recently developed novel class of oral antidiabetic drugs, are small molecular inhibitors of DPP4.

In addition, PPNs are highly effective angiotensin-converting enzyme (ACE) (EC 3.4.15.1) inhibitors (Shukor et al. 2013). Hypertension and type 2 DM (T2DM) are two closely related metabolic disorders. ACE, a central component of the renin-angiotensin system (RAS), controls blood pressure by regulating the volume of fluids in the body, playing a role in the conversion of the angiotensin I hormone into active vasoconstrictor angiotensin II (Ang II) (Carey 2015).

Ang II raises blood pressure through various processes, principally vasoconstriction, sympathetic nervous stimulation, increased aldosterone biosynthesis, and renal actions (Fyhrquist et al. 1995). Therefore, the inhibition of ACE may play a key role in the control of hypertension and cardiovascular disease (Segura Campos et al. 2013).
Recent literature has indicated that all tested samples of agro-waste citrus fruit peels demonstrated promising biological activities in terms of the decrease in serum cholesterol, triacylglyceride, and glucose levels (Fayek et al. 2017).

\section{Materials and methods}

\subsection{Chemicals and reagents}

Primary antibodies, CD26 polyclonal antibody, and antiGlut 4 antibodies were provided by Invitrogen Thermo Fisher Scientific (Waltham, MA, USA). Trypsin-EDTA, trypan blue, and penicillin-streptomycin were supplied by GibcoBRL. Cosmic calf serum was supplied by Hyclone Laboratories (South Logan, UT, USA). Dimethyl sulfoxide and 3-(4,5-dimethyl-2-thiazolyl)-2,5-diphenyl- $2 \mathrm{H}$-tetrazolium bromide (methylthiazole tetrazolium, MTT) were products of E. Merck (Dresden, Germany). Other chemicals not referred to here were products of Sigma-Aldrich Chemical Co. (St. Louis, MO, USA).

\subsection{Source of cell lines}

RINm5F (ATCC CRL-11605), RAW 264.7 (ATCC TIB71), and HepG2 cells (ATCC HB-8065) were purchased from the Bioresource Collection and Research Center of the Food Industry Research and Development Institute (Hsinchu, Taiwan).

\subsection{Western blotting}

Cells were cultured in a 6-well dish and harvested for the experiments or, for signaling experiments, incubated in a serum-free basal medium for $24 \mathrm{~h}$. The following protocols were carried out following the manufacturer's instructions (Qproteome Cell Compartment Kit protocol for standard Western blotting and signaling experiments or with lysis buffer from Qiagen [Hilden, Germany] for protein fractionation). SDS-PAGE was conducted according to BioRad (Munich, Germany). The phosphoprotein signals were detected by anti-pAkt (Ser473; 1:1000; Cell Signaling Technology, Danvers, MA, USA) or by anti-pERK (Thr202/ Tyr204; 1:500; Cell Signaling Technology, Danvers, MA, USA) and secondary anti-mouse antibodies (Dianova, Hamburg, Germany). The quantification of the ECL-developed bands was performed through a densitometric analysis with ImageJ software. The optical density was normalized to the loading control. 


\subsection{Source of grapefruits and pretreatment}

Fresh Buntan grapefruit (C. grandis [L.] Osbeck cv. Bun$\tan )$ was purchased from Dou-Liou City, Yuin-Lin County; Hsi grapefruit (C. grandis [L.] Osbeck f. Buntan Hayata) was provided by Huatan Township, Chang-Hua County, and C. grandis Osbeck cv. Peiyu was from Ershui Township, Chang-Hua County (Fig. 1). These samples were transported directly to the laboratory to be immediately rinsed. After being rinsed and blow-dried, the fruits were separated into pulp and peels. Peels were further separated into exocarps, mesocarps, and lamellae. These subparts were blow-dried at $60{ }^{\circ} \mathrm{C}$ for $24 \mathrm{~h}$. In addition, the exocarps were hot-extracted

\section{A Citrus grandis L. Osbeck cv. Buntan}

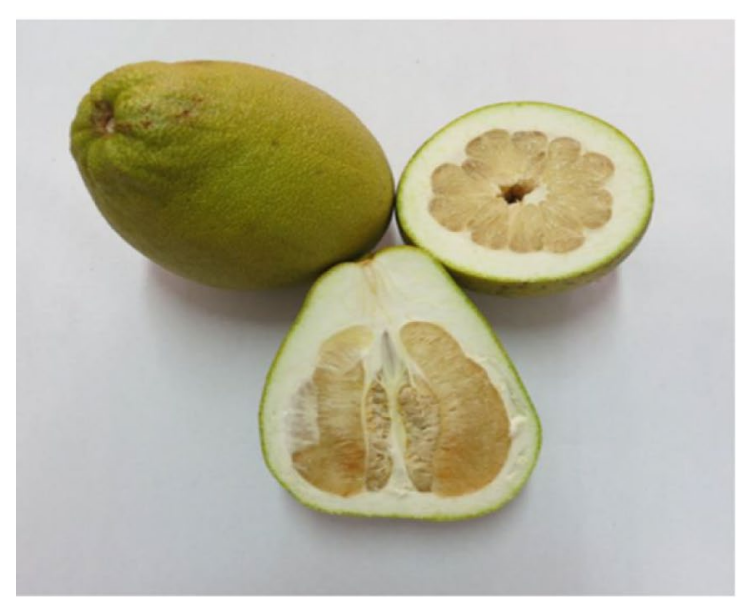

\section{Citrus grandis Osbeck, Peiyu}

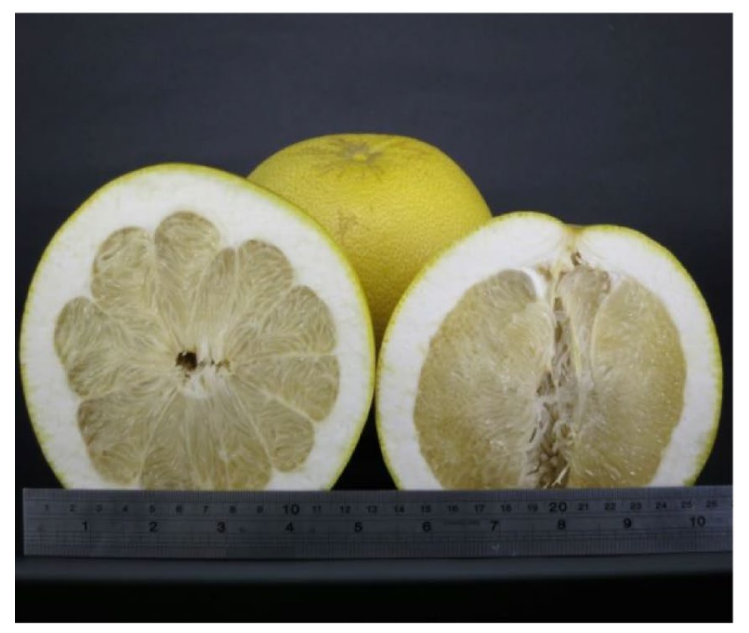

Fig. 1 Cross section view of the experimental grapefruits. In Taiwan, Citrus grandis L. Osbeck cv. Buntan has been commonly named as 'Buntan'; Citrus grandis L. Osbeck f. Buntan Hayata, Oroblanco, with steam. The waste water and the residues were separately called waste blanching water (WBW) and waste blanching exocarps (WBE). These wastes were separately lyophilized or blow-dried at $60{ }^{\circ} \mathrm{C}$ for $24 \mathrm{~h}$. The desiccated powders were separately subjected to analysis for active constituents, including polyphenolic acids, isoflavonoids, and limonoids, and in parallel subjected to extraction with water, methanol, and ethanol. The three extracts were separately blow-dried at $60^{\circ} \mathrm{C}$. The desiccated powders were analyzed in vitro for their antioxidative capabilities (i.e., total polyphenolic content, DPPH free radical scavenging capability [FRSC], and total antioxidative capability), antimicrobial bioactivity, anti-inflammatoy bioactivity (regarding TNF- $\alpha$

\section{B Citrus grandis L. Osbeck f. Buntan} Hayata

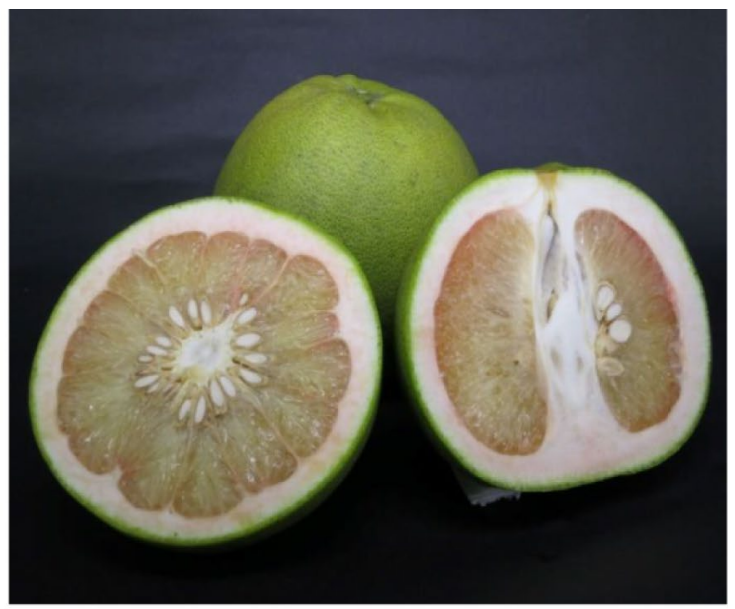

as'Hsi grapefruit', which means 'Beauty grapefruit'; Citrus grandis Osbeck, Peiyu, called 'Peiyu', which means 'White grapefruit' 
in Raw 264.7 cells), antihypertensive bioactivity (regarding ACE inhibition), and antihyperglycemic bioactivity (inhibition of $\alpha$-glucosidase, $\alpha$-amylase, and anti-insulin secretion in RINm5F cells).

\subsection{Determination of polyphenolic acids and isoflavonoids}

First, $5 \mathrm{~mL}$ of absolute methanol was added to $0.2 \mathrm{~g}$ of a desiccated sample, and the mix was ultrasonicated for $2 \mathrm{~h}$ and centrifuged; the subsequent protocol was conducted according to $\mathrm{Li}$ et al. (2006) using Hitachi HPLC with an L-2400 UV detector monitoring at $280 \mathrm{~nm}$ and eluted in a programmed solvent flow. The mobile phase contained two solutions; solution A was 10\% methanol containing $0.05 \%$ formic acid, and solution B was $100 \%$ methanol containing $0.05 \%$ formic acid. The flow rate was $1.0 \mathrm{~mL} / \mathrm{min}$. The elution was programmed as follows (A:B in \%): at $0 \mathrm{~min}$, 100:0.0; at $5 \mathrm{~min}, \mathrm{~A}: \mathrm{B}=80: 20$; at $35 \mathrm{~min}, \mathrm{~A}: \mathrm{B}=45: 55$; at $70 \mathrm{~min}, 35: 55$; at $75 \mathrm{~min}, 35: 65$; at $80-85 \mathrm{~min}, 0.0: 100$; and at 90-95 $\mathrm{min}, 100: 0.0$. Data were analyzed with Hitachi Model D-2000 Elite Chromatography Data Station Software.

\subsection{Analysis of total polyphenolics}

The method of Sato et al. (1996) was followed to determine the total polyphenolics. The content of PPNs was expressed as micrograms gallic acid equivalent per milliliter $(\mu \mathrm{g} \mathrm{GE} / \mathrm{mL})$.

\subsection{Analysis of total isoflavonoids}

The protocol of Tsai et al. (2007) was followed for the isoflavonoid content assay. Authentic quercetin (in methanol) was similarly treated to establish the calibration curve. The content of isoflavonoids was calculated and expressed in milligrams quercetin equivalent per milliliter $(\mathrm{mg} \mathrm{QE} / \mathrm{mL})$.

\subsection{Determination of limonoids}

The method of Sun et al. (2005) was followed to determine the content of limonoids using Hitachi HPLC equipped with an L-2130 pump and, a Hitachi UV Detector L-2400 monitoring at $210 \mathrm{~nm}$. The mobile phase was a mixed solution made of acetonitrile: methanol: deionized water $=50: 12: 38(\mathrm{v} / \mathrm{v})$. The flow rate was $1.0 \mathrm{~mL} / \mathrm{min}$. Data were analyzed with Hitachi Model D-2000 Elite Chromatography Data Station Software.

\subsection{Antioxidant activity}

\subsubsection{Trolox equivalent antioxidant capacity}

The assay protocol for the Trolox equivalent antioxidant capacity (TEAC) was carried out according to Miller et al.
(1993). The optical density was read at $734 \mathrm{~nm}$. The authentic Trolox solutions were prepared to contain Trolox from 1.0 to $500.0 \mu \mathrm{g} / \mathrm{mL}$. The regressed calibration curve was used for the calculation of the TEAC. A blank test was performed under the same condition. The scavenging capability was expressed as follows:

Scavenge rate $(\%)=\left[1-\left(A_{\mathrm{s}} / A_{\mathrm{c}}\right)\right] \times 100$

where $A_{\mathrm{s}}$ is the sample OD after addition of ABTS solution, and $A_{\mathrm{c}}$ is the OD of blank ABTS solution.

\subsubsection{DPPH free radical scavenging capability}

The method described by Lin et al. (2008) was followed to determine the DPPH free radical scavenging capability, which was expressed as follows:

Scavenge rate $(\%)=\left[1-\left(A_{\mathrm{s}} / A_{\mathrm{c}}\right)\right] \times 100$

where $A_{\mathrm{s}}$ denotes the OD obtained in sample solution with $\mathrm{DPPH}$, and $A_{\mathrm{c}}$ is the OD of a blank DPPH solution.

\subsection{Anti-inflammatory bioactivity}

\subsubsection{Activation of macrophage RAW264.7 cells}

The mice macrophage RAW264.7 cell line frozen in liquid nitrogen was quickly warmed and thawed in a $37{ }^{\circ} \mathrm{C}$ water bath, then transferred to Dulbecco's Modified Eagle Medium (containing 1\% nonessential amino acids and $10 \%$ heat-inactivated fetal bovine serum, $1-2 \mathrm{mM} \ell$-glutamine, $100 \mathrm{U}$ of penicillin $/ \mathrm{mL}$, and $100 \mu \mathrm{g}$ of streptomycin $/ \mathrm{mL}$ ), and incubated at $37{ }^{\circ} \mathrm{C}$ under an atmosphere of $5 \% \mathrm{CO}_{2} / 95 \%$ air (Sigma, St. Louis, MO, USA).

\subsubsection{Viability test for RAW 264.7 cells through MTT assay}

The RAW264.7 cell line was seeded onto a 24-well plate at a density of $2 \times 10^{5} /$ well and incubated at $37^{\circ} \mathrm{C}$ under an atmosphere of $5 \% \mathrm{CO}_{2} / 95 \%$ air for $48 \mathrm{~h}$. Various concentrations of grapefruit extracts $(0.5,5.0,10.0,50.0$, and $100 \mu \mathrm{g} /$ $\mathrm{mL}$ ) were added to the mixture and incubated at $37^{\circ} \mathrm{C}$ under an atmosphere of $5 \% \mathrm{CO}_{2} / 95 \%$ air for $24 \mathrm{~h}$. Subsequently, $300 \mu \mathrm{L}$ MTT $(1 \mathrm{mg} / \mathrm{mL})$ reagent was added and left to react for $1 \mathrm{~h}$ avoiding direct sunlight. The supernatant was collected and then $200 \mu \mathrm{L}$ of DMSO was added to dissolve the purple formazan crystal. The optical density was read at $570 \mathrm{~nm}$ against a blank with an enzyme-linked immunosorbent assay (ELISA) reader. 


\subsubsection{TNF- $\alpha$ analysis using ELISA}

The ELISA for TNF- $\alpha$ was carried out by following the instructions given by Bender MedSystems Co. (eBioscience, Vienna, Austria). In brief, the RAW264.7 cells at a density of $2 \times 10^{5}$ cells $/ \mathrm{mL}$ were seeded onto each well and incubated for $24 \mathrm{~h}$ before being treated with positive control lipopolysaccharide (LPS, $5 \mathrm{mg} / \mathrm{mL}$ ) for $24 \mathrm{~h}$ to trigger the expression of TNF- $\alpha$. Various appropriately diluted ethanolic extract samples from distinct parts of the grapefruits $(100 \mu \mathrm{L})$ or standard TNF- $\alpha(100 \mu \mathrm{L})$ were added as indicated, and the mixture was incubated for $2 \mathrm{~h}$. The supernatant was removed, and the residue was repeatedly rinsed with $400 \mu \mathrm{L}$ wash buffer five times to remove unbound antibodies. The optical density was read at $450 \mathrm{~nm}$. The level of TNF- $\alpha$ was calculated from the calibration curve established with standard TNF- $\alpha$ and expressed as mean \pm SD.

\subsection{Antihyperglycemic bioactivity}

\subsubsection{Assay for the inhibitory bioactivity of a-amylase}

According to the method described by Pinto et al. (2010), the extract was dissolved in $0.02 \mathrm{M}$ phosphate buffer (containing $0.006 \mathrm{M} \mathrm{NaCl}, \mathrm{pH} 6.9$ ), and an aliquot of $200 \mu \mathrm{L}$ was measured, mixed with $200 \mu \mathrm{L} \alpha$-amylase $(10 \mathrm{U} / \mathrm{mL})$, and left to react at $25^{\circ} \mathrm{C}$ for $10 \mathrm{~min}$. Subsequently, $1 \mathrm{~mL}$ of dinitrosalicylic acid coloring agent (1.0\%) was added, heated in a boiling water bath for $5 \mathrm{~min}$, cooled to ambient temperature, and diluted with $10 \mathrm{~mL}$ distilled water. The optical density was read at $540 \mathrm{~nm}$ against the buffer blank. In parallel, a $200-\mu \mathrm{L}$ sample solution was mixed with $200 \mu \mathrm{L}$ phosphate buffer and similarly treated as in the aforementioned method.

The percent inhibition of $\alpha$-amylase was calculated as:

$\%$ inhibition $=\left\{\left[\left(A_{\mathrm{c} \alpha}-A_{\mathrm{c}}\right)-\left(A_{\mathrm{s} \alpha}-A_{\mathrm{s}}\right)\right] /\left(A_{\mathrm{c} \alpha}-A_{\mathrm{c}}\right)\right\} \times 100$, where $A_{\mathrm{c} \alpha}$ is blank containing $\alpha$-amylase, $A_{\mathrm{c}}$ is blank not containing $\alpha$-amylase, $A_{\mathrm{s} \alpha}$ is sample containing $\alpha$-amylase, and $A_{\mathrm{s}}$ is sample not containing $\alpha$-amylase.

\subsubsection{Assay for the inhibitory bioactivity of a-glucosidase}

The method described by Sheng et al. (2014) was used for $\alpha$-glucosidase activity assay. In brief, $100 \mu \mathrm{L}$ extract solution (in $0.02 \mathrm{M}$ sodium phosphate solution containing $0.006 \mathrm{M}$ $\mathrm{NaCl}, \mathrm{pH} 6.9)$ and $100 \mu \mathrm{L} \alpha$-glucosidase solution (1.0 U/ $\mathrm{mL}$ ) were mixed in a 96-well plate and incubated at $25^{\circ} \mathrm{C}$ for $10 \mathrm{~min}$. Fifty microliters $p$-NPG $(5 \mathrm{mM}$ dissolved in $0.02 \mathrm{M}$ phosphate buffer containing $0.006 \mathrm{M} \mathrm{NaCl}, \mathrm{pH} 6.9$ ) was added to the reaction mixture and incubated at $25^{\circ} \mathrm{C}$ for $5 \mathrm{~min}$. The optical density was read at $405 \mathrm{~nm}$ (OD denoted as $A_{\mathrm{s}, \alpha}$ ) with an ELISA analyzer against the buffer blank
(OD denoted as $A_{\mathrm{c}}$ ). In addition, $100 \mu \mathrm{L}$ sample solution was mixed with $100 \mu \mathrm{L}$ buffer solution, and the optical density was measured (OD denoted as $A_{\mathrm{s}}$ ). The optical density was also measured for the solution made of $100 \mu \mathrm{L} \alpha$-glucosidase solution $(1.0 \mathrm{U} / \mathrm{mL})$ and $100 \mu \mathrm{L}$ buffer solution (OD denoted as $\left.A_{\mathrm{c}, \alpha}\right)$. The percent inhibition of $\alpha$-glucosidase bioactivity $\left(\% I_{\alpha G}\right)$ was expressed as follows:

$\left.\% I_{\alpha G}=\left\{\left[\left(A_{\mathrm{c}, \alpha}-A_{\mathrm{c}}\right)-\left(A_{\mathrm{s}, \alpha}-A_{\mathrm{s}}\right)\right] /\left(A_{\mathrm{c}, a}-A_{c}\right)\right]\right\} \times 100$

\subsection{Assay for in vivo insulin inductivity}

\subsubsection{Cell viability test through MTT assay for RINm5F cell line}

RINm5F cells, after being activated, were seeded onto a 24-well plate at a density of $2 \times 10^{5} /$ well and incubated under an atmosphere of $5 \% \mathrm{CO}_{2} / 95 \%$ air for $24 \mathrm{~h}$. The cells were treated with various grapefruit extracts at concentrations of $0.01,0.05,0.50$, and $100 \mu \mathrm{g} / \mathrm{mL}$ and incubated at $37^{\circ} \mathrm{C}$ for $24 \mathrm{~h}$ under an atmosphere of $5 \% \mathrm{CO}_{2} / 95 \%$ air. Subsequently, $300 \mu \mathrm{L}$ MTT $(1 \mathrm{mg} / \mathrm{mL})$ reagent was added and left to react for $1 \mathrm{~h}$ avoiding direct sunlight. The supernatant was collected and $200 \mu \mathrm{L}$ of DMSO was added to dissolve the purple formazan crystal. The optical density was read at $570 \mathrm{~nm}$ with an ELISA reader.

\subsubsection{ELISA for insulin}

An Insulin Human ELISA Kit (Invitrogen, Thermo Fisher Scientific) was used to carry out the ELISA for insulin by following the instructions given by the manufacturer. The optical density was read against a blank with an ELISA reader at $450 \mathrm{~nm}$. A calibration curve was established using a standard insulin solution treated in the same manner. The level of insulin was derived from the calibration curves. The data obtained were statistically treated and expressed as mean $\pm \mathrm{SD}$.

\subsection{Antihypertensive}

\subsubsection{Assay for the Anti-ACE Activity}

The method of Erez et al. (2011) was followed for the ACE assay. The amounts of hippuric acid produced were compared by calculating the area under peaks (denoted as $A_{\mathrm{s}}$ for the samples) or directly calculated from the regressed calibration curve established from the standard hippuric acid (Reagent C). In parallel, the buffer containing $300 \mathrm{mM}$ $\mathrm{NaCl}$ to replace the sample solution was used as the control 
Table 1 Level of phenolic acids present in various parts and waste blanching water from different grape fruits

\begin{tabular}{|c|c|c|c|c|c|}
\hline \multirow[t]{2}{*}{ Compounds } & \multicolumn{5}{|l|}{ Part of pomelo } \\
\hline & Exocarp & Mesocarp & Lamella & WBW & WBE \\
\hline \multicolumn{6}{|c|}{ Content of phenolic acids $(\mu \mathrm{g} / \mathrm{g})$, on dry basis } \\
\hline \multicolumn{6}{|c|}{ (a) Buntan } \\
\hline Gallic acid & $63.63 \pm 1.47^{\mathrm{b}}$ & $19.53 \pm 3.29^{c}$ & $12.05 \pm 0.58^{\mathrm{b}}$ & $55.68 \pm 3.13^{\mathrm{a}}$ & n.d \\
\hline Protocatechuic acid & $97.62 \pm 9.11^{\mathrm{b}}$ & $82.38 \pm 0.15^{\mathrm{c}}$ & $267.55 \pm 3.53^{\mathrm{d}}$ & $373.45 \pm 20.87^{\mathrm{a}}$ & $9.16 \pm 0.13^{\mathrm{d}}$ \\
\hline Chlorogenic acid & $171.71 \pm 11.27^{\mathrm{b}}$ & $145.02 \pm 25.33^{\mathrm{b}}$ & $557.71 \pm 39.09^{\mathrm{a}}$ & $309.24 \pm 0.88$ & $55.12 \pm 2.19^{\mathrm{c}}$ \\
\hline Caffeic acid & $54.29 \pm 6.82^{\mathrm{c}}$ & $150.98 \pm 22.02^{\mathrm{a}}$ & $87.91 \pm 16.54^{\mathrm{b}}$ & $415.68 \pm 15.38^{\mathrm{bc}}$ & $18.98 \pm 1.56^{\mathrm{d}}$ \\
\hline Ferulic acid & $4.35 \pm 0.92^{\mathrm{c}}$ & $7.31 \pm 0.66^{\mathrm{b}}$ & $99.72 \pm 3.59^{\mathrm{a}}$ & $312.58 \pm 0.21^{\mathrm{c}}$ & n.d \\
\hline Coumaric acid & $14.10 \pm 0.23^{\mathrm{c}}$ & $6.83 \pm 1.17^{\mathrm{d}}$ & $12.22 \pm 3.07^{\mathrm{b}}$ & $75.15 \pm 3.32^{\mathrm{a}}$ & $8.74 \pm 0.75^{\mathrm{d}}$ \\
\hline Total & $405.71 \pm 3.55^{\mathrm{c}}$ & $412.06 \pm 0.27^{\mathrm{c}}$ & $1037.16 \pm 72.93^{b}$ & $1541.78 \pm 5.91^{\mathrm{a}}$ & $92.00 \pm 24.96^{\mathrm{c}}$ \\
\hline \multicolumn{6}{|l|}{ (b) Buntan Hayata } \\
\hline Gallic acid & $20.39 \pm 3.52^{\mathrm{b}}$ & $3.29 \pm 0.17^{\mathrm{d}}$ & $8.14 \pm 0.76^{\mathrm{c}}$ & $27.94 \pm 2.03^{\mathrm{a}}$ & n.d \\
\hline Protocatechuic acid & $25.31 \pm 0.02^{\mathrm{b}}$ & $22.63 \pm 5.27^{\mathrm{b}}$ & $30.99 \pm 4.41^{\mathrm{b}}$ & $190.51 \pm 7.43^{\mathrm{a}}$ & $3.16 \pm 0.05^{\mathrm{c}}$ \\
\hline Chlorogenic acid & $191.55 \pm 36.68^{\mathrm{c}}$ & $38.24 \pm 6.73^{\mathrm{d}}$ & $436.40 \pm 46.37^{\mathrm{a}}$ & $317.04 \pm 20.06^{\mathrm{b}}$ & $24.69 \pm 0.52^{\mathrm{d}}$ \\
\hline Caffeic acid & $172.54 \pm 9.64^{\mathrm{c}}$ & $161.28 \pm 40.52^{\mathrm{c}}$ & $254.03 \pm 15.00^{\mathrm{b}}$ & $406.24 \pm 24.45^{\mathrm{a}}$ & $61.01 \pm 5.28^{\mathrm{d}}$ \\
\hline Ferulic acid & $3.48 \pm 2.03^{\mathrm{b}}$ & $3.74 \pm 0.56^{\mathrm{b}}$ & $37.38 \pm 3.91^{\mathrm{a}}$ & $33.92 \pm 34.31^{\mathrm{a}}$ & n.d \\
\hline Coumaric acid & $92.40 \pm 15.14^{\mathrm{a}}$ & $12.88 \pm 3.57^{\mathrm{c}}$ & $13.75 \pm 0.68^{c}$ & $39.16 \pm 3.60^{\mathrm{b}}$ & $7.39 \pm 0.49^{c}$ \\
\hline Total & $505.67 \pm 59.95^{\mathrm{c}}$ & $242.06 \pm 56.82^{\mathrm{d}}$ & $780.69 \pm 71.12^{b}$ & $1014.80 \pm 61.88^{\mathrm{a}}$ & $90.86 \pm 6.27^{\mathrm{e}}$ \\
\hline \multicolumn{6}{|l|}{ (c) Peiyu } \\
\hline Gallic acid & $9.54 \pm 1.32^{\mathrm{b}}$ & $5.95 \pm 1.53^{b}$ & $7.98 \pm 0.27^{b}$ & $60.67 \pm 21.02^{\mathrm{a}}$ & n.d \\
\hline Protocatechuic acid & $286.43 \pm 1.22^{\mathrm{a}}$ & $18.17 \pm 2.12^{\mathrm{c}}$ & $295.43 \pm 4.77^{\mathrm{a}}$ & $254.45 \pm 29.69^{b}$ & $29.90 \pm 6.93^{c}$ \\
\hline Chlorogenic acid & $68.11 \pm 7.89^{c}$ & $133.64 \pm 15.58^{\mathrm{ab}}$ & $161.76 \pm 9.65^{\mathrm{a}}$ & $111.14 \pm 35.25^{\mathrm{b}}$ & $24.45 \pm 0.87^{\mathrm{d}}$ \\
\hline Caffeic acid & $139.62 \pm 1.07^{\mathrm{b}}$ & $216.77 \pm 7.05^{\mathrm{a}}$ & $75.63 \pm 1.62^{\mathrm{c}}$ & $240.62 \pm 22.71^{\mathrm{a}}$ & $56.78 \pm 5.24^{\mathrm{c}}$ \\
\hline Ferulic acid & $2.88 \pm 0.69^{\mathrm{b}}$ & $11.60 \pm 0.66^{\mathrm{b}}$ & $19.21 \pm 0.01^{\mathrm{b}}$ & $120.23 \pm 30.03^{\mathrm{a}}$ & n.d \\
\hline Coumaric acid & $40.85 \pm 1.07^{\mathrm{b}}$ & $24.21 \pm 3.13^{\mathrm{c}}$ & $23.82 \pm 2.90^{c}$ & $102.08 \pm 8.66^{\mathrm{a}}$ & $4.13 \pm 0.23^{\mathrm{d}}$ \\
\hline Total & $547.44 \pm 8.67^{\mathrm{bc}}$ & $410.34 \pm 25.97^{\mathrm{c}}$ & $583.83 \pm 0.64^{\mathrm{b}}$ & $889.19 \pm 147.35^{\mathrm{a}}$ & $115.26 \pm 0.58^{\mathrm{d}}$ \\
\hline
\end{tabular}

Data are expressed as mean $\pm \mathrm{SD}(n=3)$. Superscript letters in the same column indicate significant difference $(p<0.05)$

n.d. not detected, WBW waste blanching water, WBE waste blanching water from exocarps

(denoted as $A_{\mathrm{c}}$ ). The percent ACE inhibition was calculated as follows:

$\%$ ACE inhibition $=\left[\left(A_{\mathrm{c}}-A_{\mathrm{s}}\right) / A_{\mathrm{c}}\right] \times 100$

\subsection{Statistical analysis}

Data obtained were analyzed using SPSS10.0 (SPSS, Chicago, USA) through one-way analysis of variance to evaluate the deviation in the same group. Duncan's multiple range test was used to compare the significant difference among groups. Data were expressed as mean \pm SEM for all experimental measurements based on triplicate results $(n=3)$. Significant differences were considered at $p<0.05$.

\section{Results}

\subsection{Abundant polyphenolics and flavonoids present in grapefruits and WBW}

Table 1 presents the abundant polyphenolics present in all parts of the fruit as well as in the WBW, including gallic acid, protocatechuic acid, chlorogenic acid, caffeic acid, ferulic acid, and coumaric acid (Table 1). Regarding the fruit part, the most abundant polyphenolics present in the exocarp of Buntan grapefruit was gallic acid $(63.63 \pm 1.47 \mu \mathrm{g} / \mathrm{g})$ (Table 1a); protocatechuic acid $(267.55 \pm 3.53 \mu \mathrm{g} / \mathrm{g})$ in the lamella of Buntan Hayata (Table 1b); chlorogenic acid $(557.71 \pm 39.09 \mu \mathrm{g} / \mathrm{g})$ in the lamella of Bundan (Table 1a); caffeic acid $(254.03 \pm 15.00 \mu \mathrm{g} / \mathrm{g})$ in the lamella of Bundan Hayata (Table 1b); ferulic acid $(99.72 \pm 3.59 \mu \mathrm{g} / \mathrm{g})$ in the lamella of Bundan (Table 1a); and coumaric acid $(40.85 \pm 1.07 \mu \mathrm{g} / \mathrm{g})$ in the exocarp of Peiyu (Table 1c). Notably, a considerable amount of polyphenolics compounds appeared in the WBW of Bundan, 
Table 2 Level of flavonoids in various fruit parts and waste blanching water from different grape fruits

\begin{tabular}{|c|c|c|c|c|c|}
\hline \multirow[t]{2}{*}{ Compounds } & \multicolumn{5}{|l|}{ Part of pomelo } \\
\hline & Exocarp & Mesocarp & Lamella & WBW & WBE \\
\hline \multicolumn{6}{|c|}{ Content of flavonoids $(\mathrm{mg} / \mathrm{g})$, on dry basis } \\
\hline \multicolumn{6}{|c|}{ (a) Buntan } \\
\hline Naringin & $8.53 \pm 0.06^{\mathrm{b}}$ & n.d & $0.86 \pm 0.11^{\mathrm{d}}$ & $21.72 \pm 0.55^{\mathrm{a}}$ & $2.59 \pm 0.01^{\mathrm{c}}$ \\
\hline Hesperidin & $2.48 \pm 0.29^{\mathrm{b}}$ & $12.63 \pm 0.45^{\mathrm{a}}$ & $2.56 \pm 0.16^{\mathrm{b}}$ & $1.39 \pm 0.75^{\mathrm{c}}$ & $1.76 \pm 0.07^{\mathrm{c}}$ \\
\hline Diosmin & $10.39 \pm 0.29^{b}$ & $0.02 \pm 0.02^{\mathrm{d}}$ & $11.59 \pm 2.83^{\mathrm{b}}$ & $42.28 \pm 6.90^{\mathrm{a}}$ & $2.76 \pm 0.09^{c}$ \\
\hline Quercetin & $11.15 \pm 0.43^{\mathrm{a}}$ & n.d & n.d & $11.09 \pm 0.24^{\mathrm{a}}$ & $1.51 \pm 0.10^{\mathrm{b}}$ \\
\hline Hesperitin & $1.06 \pm 0.74^{\mathrm{a}}$ & $0.87 \pm 0.04^{\mathrm{a}}$ & $0.84 \pm 0.23^{\mathrm{a}}$ & $0.54 \pm 0.05^{\mathrm{a}}$ & $0.48 \pm 0.01^{\mathrm{a}}$ \\
\hline Nobiletin & $1.04 \pm 0.03^{\mathrm{a}}$ & n.d & n.d & $1.17 \pm 0.02^{\mathrm{a}}$ & $0.23 \pm 0.00^{\mathrm{b}}$ \\
\hline Tangeretin & $4.23 \pm 0.84^{\mathrm{b}}$ & $5.63 \pm 0.22^{\mathrm{b}}$ & $11.29 \pm 3.15^{\mathrm{a}}$ & $4.04 \pm 0.75^{\mathrm{b}}$ & $1.24 \pm 0.02^{\mathrm{c}}$ \\
\hline Total & $38.89 \pm 1.98^{\mathrm{b}}$ & $19.15 \pm 0.17^{\mathrm{d}}$ & $27.38 \pm 5.46^{\mathrm{c}}$ & $82.23 \pm 2.28^{\mathrm{a}}$ & $10.56 \pm 0.07^{\mathrm{e}}$ \\
\hline \multicolumn{6}{|c|}{ (b) Buntan Hayata } \\
\hline Naringin & $11.41 \pm 0.94^{\mathrm{b}}$ & $13.55 \pm 3.38^{\mathrm{b}}$ & $15.49 \pm 1.59^{\mathrm{b}}$ & $21.44 \pm 1.41^{\mathrm{a}}$ & $2.83 \pm 0.17^{\mathrm{c}}$ \\
\hline Hesperidin & $0.60 \pm 0.01^{\mathrm{c}}$ & $0.51 \pm 0.01^{\mathrm{bc}}$ & $0.59 \pm 0.02 b^{c}$ & $0.77 \pm 0.05^{\mathrm{b}}$ & $1.17 \pm 0.06^{\mathrm{a}}$ \\
\hline Diosmin & $9.39 \pm 0.55^{\mathrm{a}}$ & $5.50 \pm 1.18^{\mathrm{bc}}$ & $6.31 \pm 0.86^{\mathrm{b}}$ & $9.03 \pm 0.04^{\mathrm{a}}$ & $5.78 \pm 0.49 b^{c}$ \\
\hline Quercetin & $3.90 \pm 0.23^{\mathrm{a}}$ & $0.95 \pm 0.13^{\mathrm{b}}$ & $0.34 \pm 0.22^{c}$ & $3.75 \pm 0.02^{\mathrm{a}}$ & $0.73 \pm 0.08^{\mathrm{b}}$ \\
\hline Hesperitin & $2.22 \pm 0.14^{\mathrm{c}}$ & $11.16 \pm 0.52^{\mathrm{a}}$ & $11.39 \pm 0.77^{\mathrm{a}}$ & $2.11 \pm 0.87^{\mathrm{c}}$ & $3.71 \pm 0.15^{b}$ \\
\hline Nobiletin & $0.50 \pm 0.07^{c}$ & n.d & n.d & $1.27 \pm 0.04^{\mathrm{a}}$ & $1.10 \pm 0.06^{\mathrm{b}}$ \\
\hline Tangeretin & $4.64 \pm 0.11^{b}$ & $25.20 \pm 0.05^{\mathrm{a}}$ & $19.82 \pm 6.11^{\mathrm{a}}$ & $8.32 \pm 0.50^{\mathrm{b}}$ & $9.81 \pm 0.28^{b}$ \\
\hline Total & $32.66 \pm 0.28^{\mathrm{c}}$ & $56.86 \pm 5.16^{\mathrm{a}}$ & $53.93 \pm 7.58^{\mathrm{a}}$ & $46.69 \pm 0.07^{b}$ & $25.13 \pm 0.68^{c}$ \\
\hline \multicolumn{6}{|l|}{ (c) Peiyu } \\
\hline Naringin & $14.44 \pm 0.20^{\mathrm{b}}$ & $23.49 \pm 1.27^{\mathrm{a}}$ & $16.93 \pm 0.45^{\mathrm{b}}$ & $25.53 \pm 2.32^{\mathrm{a}}$ & $4.36 \pm 0.64^{\mathrm{c}}$ \\
\hline Hesperidin & $0.50 \pm 0.01^{\mathrm{d}}$ & $0.56 \pm 0.00 \mathrm{~cd}$ & n.d & $0.83 \pm 0.17^{\mathrm{a}}$ & $0.77 \pm 0.16^{\mathrm{ab}}$ \\
\hline Diosmin & $10.85 \pm 0.17^{\mathrm{d}}$ & $15.59 \pm 1.87^{\mathrm{c}}$ & $20.17 \pm 3.84^{\mathrm{b}}$ & $30.76 \pm 0.44^{\mathrm{a}}$ & $1.56 \pm 0.08^{\mathrm{e}}$ \\
\hline Quercetin & $3.10 \pm 0.11^{\mathrm{a}}$ & n.d & n.d & $2.60 \pm 0.47^{b}$ & $0.41 \pm 0.09^{c}$ \\
\hline Hesperitin & $1.20 \pm 0.04^{\mathrm{b}}$ & $9.15 \pm 3.61^{\mathrm{a}}$ & $12.29 \pm 0.48^{\mathrm{a}}$ & $2.76 \pm 0.12^{\mathrm{b}}$ & $3.58 \pm 0.59^{\mathrm{b}}$ \\
\hline Nobiletin & $0.19 \pm 0.01^{\mathrm{b}}$ & n.d & n.d & $0.42 \pm 0.24^{\mathrm{ab}}$ & $0.61 \pm 0.00^{\mathrm{a}}$ \\
\hline Tangeretin & $4.07 \pm 0.40^{\mathrm{b}}$ & $23.03 \pm 0.61^{\mathrm{a}}$ & $19.12 \pm 3.72^{\mathrm{a}}$ & $18.62 \pm 6.50^{\mathrm{a}}$ & $8.92 \pm 0.02^{b}$ \\
\hline Total & $34.35 \pm 0.72^{c}$ & $71.82 \pm 6.14^{\mathrm{b}}$ & $68.51 \pm 1.05^{\mathrm{b}}$ & $81.54 \pm 4.41^{\mathrm{a}}$ & $20.21 \pm 1.21^{\mathrm{d}}$ \\
\hline
\end{tabular}

Data are expressed as mean \pm SD $(n=3)$. Superscript letters in the same column indicate significant difference $(p<0.05)$

n.d. not detected, WBW waste blanching water, WBE waste blanching water from exocarps such as gallic acid $(55.68 \pm 3.13 \mu \mathrm{g} / \mathrm{g})$, protocatechuic acid $(373.45 \pm 20.8 \mu \mathrm{g} / \mathrm{g})$, chlorogenic acid $(309.24 \pm 0.88 \mu \mathrm{g} / \mathrm{g})$, caffeic acid $(415.68 \pm 15.38 \mu \mathrm{g} / \mathrm{g})$, and coumaric acid $(75.15 \pm 3.32 \mu \mathrm{g} / \mathrm{g})$ (Table 1a).

These grapefruits also contained various precious flavonoids such as naringin, hesperidin, diosmin, quercetin, hesperetin, nobiletin, and tangeretin. The most abundant polyphenolics were as follows: naringin in the exocarp of Peiyu (14.44 $\pm 0.20 \mathrm{mg} / \mathrm{g}$ ) (Table $2 \mathrm{c}$ ), hesperi$\operatorname{din}(2.48 \pm 0.29 \mathrm{mg} / \mathrm{g})$ in the exocarp of Bundan (Table $2 \mathrm{a})$, diosmin $(11.59 \pm 0.283 \mathrm{mg} / \mathrm{g})$ in the exocarp of Bundan (Table $2 \mathrm{a}$ ) and $(10.85 \pm 0.17 \mathrm{mg} / \mathrm{g})$ in the exocarp of Peiyu (Table $2 \mathrm{c})$, quercetin $(11.15 \pm 0.43 \mathrm{mg} / \mathrm{g})$ in the exocarp of Buntan (Table $2 \mathrm{a}$ ), hesperetin $(12.29 \pm 0.48 \mathrm{mg} / \mathrm{g})$ in the lamella of Peiyu and $(11.39 \pm 0.77 \mathrm{mg} / \mathrm{g})$ (Table $2 \mathrm{c}$ ) in the lamella of Buntan Hayata (Table 2b), and tangeretin $(25.20 \pm 0.05 \mathrm{mg} / \mathrm{g})$ in the mesocarp of Buntan Hayata
(Table 2b) and $(23.03 \pm 0.61 \mathrm{mg} / \mathrm{g})$ in the mesocsarp of Peiyu (Table 2c). Nobiletin was only present in the exocarps in small amounts (Table $2 \mathrm{a}-\mathrm{c}$ ). Notably, there was a much larger loss of polyphenolics in the WBW from Buntan and Buntan Hayata, reaching $1541.78 \pm 5.91 \mu \mathrm{g} / \mathrm{g}$ and $1014.80 \pm 61.88 \mu \mathrm{g} / \mathrm{g}$ (Table $1 \mathrm{a}, \mathrm{b}$ ) respectively, compared with $889.19 \pm 147.35 \mu \mathrm{g} / \mathrm{g}$ from Peiyu (Table 1c). Alternately, a more considerable flavonoids loss was observed in Buntan $(82.23 \pm 2.28 \mathrm{mg} / \mathrm{g}$ ) (Table 2a) and Peiyu $(81.54 \pm 4.41 \mathrm{mg} / \mathrm{g}$ ) (Table $2 \mathrm{c})$ compared with Buntan Hayata $(46.69 \pm 0.07 \mathrm{mg} / \mathrm{g})$ (Table $2 \mathrm{~b})$. A much smaller loss was noted in the WBW of exocarp (WBE) (Tables 1, 2), implicating the cost efficient recovery of these waste polyphenolics and flavonoids from WBW. Through various solvent extractions using water, ethanol, and methanol, this suggestion was further confirmed. That is, the loss of polyphenolics and flavonoids into hot water blanching was considerable, and 
Table 3 Level of total phenolics in various parts and waste blanching water from different grape fruits

\begin{tabular}{|c|c|c|c|}
\hline \multirow[t]{3}{*}{ Pomelo parts } & \multicolumn{3}{|l|}{ Solvent } \\
\hline & \multicolumn{3}{|c|}{ Content of total phenolics (GAE mg g) } \\
\hline & Water & Ethanol & Methanol \\
\hline \multicolumn{4}{|l|}{ (a) Buntan } \\
\hline Exocarp & $1.70 \pm 0.01^{\mathrm{c}}$ & $4.18 \pm 0.03^{\mathrm{b}}$ & $5.80 \pm 0.01^{\mathrm{a}}$ \\
\hline Mesocarp & $0.99 \pm 0.01^{\mathrm{c}}$ & $2.77 \pm 0.01^{\mathrm{a}}$ & $2.06 \pm 0.01^{b}$ \\
\hline Lamella & $0.71 \pm 0.01^{\mathrm{c}}$ & $2.44 \pm 0.01^{\mathrm{a}}$ & $1.70 \pm 0.02^{b}$ \\
\hline WBW & $5.36 \pm 0.01^{\mathrm{c}}$ & $9.20 \pm 0.02^{\mathrm{a}}$ & $6.59 \pm 0.01^{b}$ \\
\hline WBE & $3.68 \pm 0.01^{\mathrm{b}}$ & $4.43 \pm 0.02^{\mathrm{a}}$ & $4.44 \pm 0.02^{\mathrm{a}}$ \\
\hline \multicolumn{4}{|c|}{ (b) Buntan Hayata } \\
\hline Exocarp & $4.12 \pm 0.01^{\mathrm{c}}$ & $5.55 \pm 0.01^{\mathrm{a}}$ & $3.46 \pm 0.02^{b}$ \\
\hline Mesocarp & $1.22 \pm 0.01^{\mathrm{c}}$ & $4.56 \pm 0.02^{\mathrm{a}}$ & $2.12 \pm 0.03^{b}$ \\
\hline Lamella & $0.02 \pm 0.01^{\mathrm{c}}$ & $3.88 \pm 0.01^{\mathrm{a}}$ & $2.44 \pm 0.03^{b}$ \\
\hline WBW & $1.40 \pm 0.01^{\mathrm{c}}$ & $9.13 \pm 0.05^{\mathrm{b}}$ & $9.65 \pm 0.02^{\mathrm{a}}$ \\
\hline WBE & $0.24 \pm 0.01^{\mathrm{c}}$ & $3.15 \pm 0.01^{\mathrm{a}}$ & $1.11 \pm 0.01^{b}$ \\
\hline \multicolumn{4}{|l|}{ (c) Peiyu } \\
\hline Exocarp & $2.25 \pm 0.05^{\mathrm{c}}$ & $4.65 \pm 0.01^{\mathrm{a}}$ & $3.39 \pm 0.02^{b}$ \\
\hline Mesocarp & $0.74 \pm 0.01^{\mathrm{c}}$ & $4.14 \pm 0.01^{\mathrm{a}}$ & $2.26 \pm 0.02^{b}$ \\
\hline Lamella & $0.45 \pm 0.01^{\mathrm{c}}$ & $3.84 \pm 0.01^{\mathrm{a}}$ & $2.53 \pm 0.01^{\mathrm{b}}$ \\
\hline WBW & $1.62 \pm 0.02^{\mathrm{c}}$ & $9.39 \pm 0.01^{\mathrm{b}}$ & $10.09 \pm 0.02^{\mathrm{a}}$ \\
\hline WBE & $1.15 \pm 0.01^{\mathrm{c}}$ & $3.51 \pm 0.04^{\mathrm{a}}$ & $1.84 \pm 0.01^{\mathrm{b}}$ \\
\hline
\end{tabular}

Data are expressed as mean $\pm \mathrm{SD}(n=3)$. Superscript letters in the same column indicate significant difference $(p<0.05)$

$n . d$. not detected, WBW waste blanching water, WBE waste blanching water from exocarps

the amount of polyphenolics and flavonoids was significant enough for efficient recovery (Tables 3,4).

\subsection{Considerable amount of limonoids present in grapefruits and WBW}

In Bundan and Bundan Hayata, limonins were abundantly present in the exocarp and lamella, respectively, at $137.45 \pm 0.07 \mathrm{mg} / 100 \mathrm{~g}$ and $116.26 \pm 5.06 \mathrm{mg} / 100 \mathrm{~g}$ in Bundan and $92.60 \pm 1.66 \mathrm{mg} / 100 \mathrm{~g}$ (Table 5a) and $147.64 \pm 4.65 \mathrm{mg} / 100 \mathrm{~g}$ in Bundan Hayata (Table $5 \mathrm{~b}$ ). The presence of nomilin was similar at $130.94 \pm 1.70 \mathrm{mg} / 100 \mathrm{~g}$ and $175.33 \pm 3.83 \mathrm{mg} / 100 \mathrm{~g}$ in Bundan (Table 5a) and $62.53 \pm 6.00 \mathrm{mg} / 100 \mathrm{~g}$ and $131.23 \pm 11.61 \mathrm{mg} / 100 \mathrm{~g}$ in Bundan Hayata (Table 5b). For Peiyu, the limonin content was the highest in lamella, $(125.85 \pm 17.87 \mathrm{mg} / 100 \mathrm{~g})$ whereas the content in the exocarp and mesocarp was relatively low (Table 5c); conversely, the content of nomilin reached $269.38 \pm 11.23 \mathrm{mg} / 100 \mathrm{~g}$ and $121.55 \pm 12.01 \mathrm{mg} / 100 \mathrm{~g}$, respectively, in the lamella and exocarp (Table 5c). The total limonoid content reached its highest at $395.24 \pm 29.10 \mathrm{mg} / 100 \mathrm{~g}$ in the lamella of Peiyu (Table 5c), followed by $291.60 \pm 8.90 \mathrm{mg} / 100 \mathrm{~g}$ and $278.86 \pm 16.26 \mathrm{mg} / 100 \mathrm{~g}$,
Table 4 Level of total flavonoids in various parts and waste blanching water from different grape fruits

\begin{tabular}{|c|c|c|c|}
\hline \multirow[t]{3}{*}{ Pomelo parts } & \multicolumn{3}{|l|}{ Solvent } \\
\hline & \multicolumn{3}{|c|}{ Content of total flavonoids (QE mg/g) } \\
\hline & Water & Ethanol & Methanol \\
\hline \multicolumn{4}{|l|}{ (a) Buntan } \\
\hline Exocarp & $12.52 \pm 0.01^{\mathrm{c}}$ & $25.93 \pm 0.02^{\mathrm{b}}$ & $33.28 \pm 0.01^{\mathrm{a}}$ \\
\hline Mesocarp & $0.41 \pm 0.01^{\mathrm{c}}$ & $3.25 \pm 0.01^{\mathrm{b}}$ & $6.44 \pm 0.01^{\mathrm{a}}$ \\
\hline Lamella & $1.00 \pm 0.01^{\mathrm{c}}$ & $1.73 \pm 0.01^{\mathrm{b}}$ & $6.56 \pm 0.01^{\mathrm{a}}$ \\
\hline WBW & $28.99 \pm 0.19^{\mathrm{b}}$ & $32.57 \pm 0.05^{\mathrm{a}}$ & $36.91 \pm 0.21^{\mathrm{a}}$ \\
\hline WBE & $10.93 \pm 0.02^{\mathrm{c}}$ & $11.10 \pm 0.01^{\mathrm{b}}$ & $18.82 \pm 0.41^{\mathrm{a}}$ \\
\hline \multicolumn{4}{|c|}{ (b) Buntan Hayata } \\
\hline Exocarp & $11.90 \pm 0.03^{\mathrm{c}}$ & $17.08 \pm 0.01^{\mathrm{b}}$ & $28.91 \pm 0.02^{\mathrm{a}}$ \\
\hline Mesocarp & $0.90 \pm 0.04^{\mathrm{c}}$ & $3.82 \pm 0.01^{\mathrm{b}}$ & $5.31 \pm 0.02^{\mathrm{a}}$ \\
\hline Lamella & $0.11 \pm 0.01^{\mathrm{c}}$ & $4.23 \pm 0.01^{\mathrm{b}}$ & $7.53 \pm 0.01^{\mathrm{a}}$ \\
\hline WBW & $18.59 \pm 0.08^{\mathrm{c}}$ & $20.77 \pm 0.03^{b}$ & $33.48 \pm 0.01^{\mathrm{a}}$ \\
\hline WBE & $0.86 \pm 0.01^{\mathrm{c}}$ & $4.01 \pm 0.05^{\mathrm{b}}$ & $8.11 \pm 0.01^{\mathrm{a}}$ \\
\hline \multicolumn{4}{|l|}{ (c) Peiyu } \\
\hline Exocarp & $8.35 \pm 0.01^{\mathrm{c}}$ & $18.11 \pm 0.01^{\mathrm{b}}$ & $29.96 \pm 0.01^{\mathrm{a}}$ \\
\hline Lamella & $0.43 \pm 0.01^{\mathrm{c}}$ & $3.49 \pm 0.01^{\mathrm{b}}$ & $7.27 \pm 0.01^{\mathrm{a}}$ \\
\hline WBW & $10.05 \pm 0.01^{\mathrm{c}}$ & $28.54 \pm 0.01^{\mathrm{b}}$ & $32.34 \pm 0.05^{\mathrm{a}}$ \\
\hline WBE & $4.41 \pm 0.01^{\mathrm{c}}$ & $6.97 \pm 0.01^{\mathrm{b}}$ & $12.79 \pm 0.01^{\mathrm{a}}$ \\
\hline
\end{tabular}

Data are expressed as mean \pm SD $(n=3)$. Superscript letters in the same column indicate significant difference $(p<0.05)$

n.d. not detected, WBW waste blanching water, WBE waste blanching water from exocarps

respectively, in the lamella of Bunda and Bundan Hayata (Table 5a, b). The total limonoids present in the WBW from Bundan Hayata were $137.84 \pm 2.45 \mathrm{mg} / 100 \mathrm{~g}$ (Table 5b), whereas the amount in the other two cultivars appeared comparatively low (Table 5a, c). Notably, all three WBEs exhibited high levels of total limonoids, reaching $287.41 \pm 10.20$, $169.05 \pm 0.73$, and $176.58 \pm 7.30 \mathrm{mg} / 100 \mathrm{~g}$, for Bundan, Bundan Hayata, and Peiyu (Table 5a-c), respectively, implicating the high cost efficiency for the recovery of these limonoids.

\subsection{Grapefruits exhibited promising antioxidative capability}

All parts of the grapefruit demonstrated promising strong antioxidative capability, particularly in the exocarp, mesocarp and lamella of Buntan (Tables 6a, 7a), the lamella of Buntan Hayata (Tables $6 \mathrm{~b}, 7 \mathrm{~b}$ ), and the excoarp, mesocarp and lamella of Peiyu (Tables 6c, 7c). Evidently, these antioxidative capabilities were due to the considerable amount of valuable polyphenolics and flavonoids present in the grapefruits (Tables 1, 2, 3, 4). 
Table 5 Level of limonoids in various parts and waste blanching water from different grape fruits

\begin{tabular}{|c|c|c|c|c|c|}
\hline \multirow[t]{2}{*}{ Compounds } & \multicolumn{5}{|l|}{ Part of Pomelo } \\
\hline & Exocarp & Mesocarp & Lamella & WBW & WBE \\
\hline \multicolumn{6}{|c|}{ Content of limonoids ( $\mathrm{mg} / 100 \mathrm{~g})$, on dry basis } \\
\hline \multicolumn{6}{|l|}{ (a) Buntan } \\
\hline Limonin & $137.45 \pm 0.07^{\mathrm{b}}$ & $15.04 \pm 0.93^{\mathrm{d}}$ & $116.26 \pm 5.06^{\mathrm{c}}$ & $22.67 \pm 0.70^{\mathrm{d}}$ & $225.32 \pm 10.11^{\mathrm{a}}$ \\
\hline Nomilin & $130.94 \pm 1.70^{\mathrm{b}}$ & $18.14 \pm 1.39^{\mathrm{e}}$ & $175.33 \pm 3.83^{\mathrm{a}}$ & $41.72 \pm 5.03^{\mathrm{d}}$ & $62.09 \pm 0.09^{c}$ \\
\hline Total & $268.38 \pm 1.63^{\mathrm{b}}$ & $33.18 \pm 2.32^{\mathrm{d}}$ & $291.60 \pm 8.90^{\mathrm{a}}$ & $64.39 \pm 4.33^{\mathrm{c}}$ & $287.41 \pm 10.20^{\mathrm{a}}$ \\
\hline \multicolumn{6}{|c|}{ (b) Buntan Hayata } \\
\hline Limonin & $92.60 \pm 1.66^{\mathrm{b}}$ & $25.12 \pm 0.49^{c}$ & $147.64 \pm 4.65^{\mathrm{a}}$ & $14.64 \pm 3.12^{\mathrm{d}}$ & $16.58 \pm 0.45^{\mathrm{d}}$ \\
\hline Nomilin & $62.53 \pm 6.00^{\mathrm{c}}$ & $51.28 \pm 5.88^{c}$ & $131.23 \pm 11.61^{\mathrm{b}}$ & $123.20 \pm 0.67^{\mathrm{b}}$ & $152.48 \pm 0.29^{\mathrm{a}}$ \\
\hline Total & $155.13 \pm 7.66^{\mathrm{b}}$ & $76.39 \pm 6.37^{\mathrm{d}}$ & $278.86 \pm 16.26^{\mathrm{a}}$ & $137.84 \pm 2.45^{\mathrm{c}}$ & $169.05 \pm 0.73^{b}$ \\
\hline \multicolumn{6}{|l|}{ (c) Peiyu } \\
\hline Limonin & $21.22 \pm 0.22^{\mathrm{cd}}$ & $25.66 \pm 0.93^{c}$ & $125.85 \pm 17.87^{\mathrm{a}}$ & $8.89 \pm 2.43^{\mathrm{d}}$ & $41.20 \pm 1.76^{\mathrm{b}}$ \\
\hline Nomilin & $121.55 \pm 12.01^{\mathrm{b}}$ & $87.74 \pm 1.49^{\mathrm{c}}$ & $269.38 \pm 11.23^{\mathrm{a}}$ & $5.09 \pm 0.19^{\mathrm{d}}$ & $135.38 \pm 6.40^{\mathrm{b}}$ \\
\hline Total & $142.77 \pm 12.23^{\mathrm{c}}$ & $113.4 \pm 2.42^{\mathrm{d}}$ & $395.24 \pm 29.10^{\mathrm{a}}$ & $15.36 \pm 0.60^{\mathrm{e}}$ & $176.58 \pm 7.30^{\mathrm{b}}$ \\
\hline
\end{tabular}

Data are expressed as mean \pm SD $(n=3)$. Superscript letters in the same column indicate significant difference $(p<0.05)$

n.d. not detected, WBW waste blanching water, WBE waste blanching water from exocarps

\subsection{Grapefruits exhibited anti-inflammatory bioactivity}

Buntan exocarp extract at $0.5-50 \mu \mathrm{g} / \mathrm{mL}$ stimulated cell viability to over $125 \%$. Conversely, LPS at $5 \mathrm{mg} / \mathrm{mL}$ reduced the cell viability to $48 \%$. Cytotoxicity occurred at a dose of $\geq 100 \mu \mathrm{g} / \mathrm{mL}$ with viability reduced to $82 \%$ (Fig. $2 \mathrm{a}$ ). Similar phenomena were observed for the Buntan mesocarp extract and the Buntan WBW (Table 2a). The extracts from Buntan Hayata and Peiyu including those from the exocarp, mesocarp, and WBW, indicated similar results (Fig. 2b, c). Evidently, LPS tended to kill the cells, and the extracts of these three grapefruits were able to potentially secure the cell viability (Fig. 3a-c). At the same time, the inflammatory marker, TNF- $\alpha$, was highly upregulated by the stimulation of LPS, which was unalleviated by low-dose extracts of Buntan exocarp and mesocarp. The effective dose only occurred at $\geq 50 \mu \mathrm{g} / \mathrm{mL}$. By contrast, the toxic effect appeared in Bun$\tan$ WBW at a dose of $\geq 10 \mu \mathrm{g} / \mathrm{mL}$ (Fig. 3a). Compared with Buntan, the Buntan Hayata exocarp extract suppressed the TNF- $\alpha$ level at $5-10 \mu \mathrm{g} / \mathrm{mL}$ in a dose-dependent manner (Fig. 3b). However, at a higher dose ( $\geq 50 \mu \mathrm{g} / \mathrm{mL})$, the toxic effect occurred. As for the Peiyu extracts from the exocarp, a dose-dependent suppression of TNF- $\alpha$ was apparent. Conversely, the extract from Peiyu mesocarp strongly upregulated the level of TNF- $\alpha$, which was entirely ineffective to suppress the level of TNF- $\alpha$. The same phenomenon was observed for Peiyu WBW (Fig. 3c).

\subsection{Grapefruits exhibited promising antihyperglycemic bioactivity}

\subsubsection{The considerable amount of limonoids contributed to the hypoglycemic effect}

Grapefruit waste extracts from the exocarp, mesocarp, lamella, WBW, and WBE of Buntan, Buntan Hayata and Peiyu contained a considerable amount of limonoids (Table 5).

\subsubsection{Cell viability of RINm5F}

Extracts at lower doses from Buntan, Buntan Hayata, and Peiyu appeared to stimulate the growth of RINm5F cells. A higher dose yielded a viability suppressing effect, which varied according to the species of grapefruit (Fig. 4a-c). For example, the minimum suppressing dose occurred at $\geq 5 \mu \mathrm{g} / \mathrm{mL}$ for Butan (Fig. 4a), at $\geq 1 \mu \mathrm{g} / \mathrm{mL}$ for Buntan Hayata (Fig. 4b), and at $\geq 500 \mathrm{ng} / \mathrm{mL}(0.5 \mu \mathrm{g} / \mathrm{mL})$ for Peiyu (Fig. 4c).

\subsubsection{Insulin release was stimulated}

Regarding the insulin release, Buntan extracts from the exocarp, mesocarp, and WBW at a dose within 10-500 ng/mL revealed a dose-dependent stimulating effect with respect to insulin release in RINm5F cells. At a dose of $500 \mathrm{ng} /$ $\mathrm{mL}$, the effect appeared to reach over a five-fold increase for the Buntan excocarp, three-fold for the Buntan mesocarp, and four-fold for the Buntan WBW (Fig. 5a). Similar results were observed for Buntan Hayata (Fig. 5b). A more effective 
(i.e., at lower doses) stimulating effect for insulin release was noted for Peiyu extracts within $5-50 \mathrm{ng} / \mathrm{mL}$. These three waste extracts dose dependently triggered the insulin release, reaching a four-fold increase at $50 \mathrm{ng} / \mathrm{mL}$ (Fig. 5c).

\subsubsection{The expression of Glut4 was significantly upregulated}

When HepG2 cells were tested for their viability, all selected polyphenolics (protocatechuic acid, caffeic acid, and coumaric acid) and flavonoids (diosmin, naringin, and hesperidin) appeared to be coexisting with the HepG2 cells (Fig. 6a), implying that in the following Glut4 and DPP4 assays, data could be directly compared without the consideration of factors influencing cell viability (i.e., the effect of cell density). Surprisingly, all selected polyphenolics and flavonoids except protocatechuic acid significantly upregulated the Glut4 expression (Fig. 6b).

\subsection{The expression of DPP4 was significantly inhibited}

At the same time, these compounds, except protocatechuic acid and caffeic acid, significantly reduced the expression of DPP4 to levels of 75-80\% compared with the control (100\%) (Fig. 6c). By contrast, caffeic acid upregulated DPP4 to $128 \%$ over the control, whereas protocatechuic acid showed a complete lack of effectiveness (Fig. 6c).

\subsection{The intracellular insulin level was highly stimulated in RINm5F cells}

Notably, protocatechuic acid, although entirely ineffective in upregulating Glut4 and DPP4 in the HepG2 cells, appeared capable to stimulate the intracellular insulin level in RINm5F cells (Fig. 7).

\subsection{Inhibitory effect on digestive enzymes- a-amylase and $a$-glucosidase}

The $\mathrm{IC}_{50}$ values of $\alpha$-amylase for the grapefruit waste extract from the exocarp, mesocarp, lamella, WBW, and WBE of Buntan ranged from $27.96 \pm 0.03 \mathrm{mg} / \mathrm{mL}$ (WBW) to $60.45 \pm 0.72 \mathrm{mg} / \mathrm{mL}$ (lamella), and those of $\alpha$-glucosidase ranged from $1.80 \pm 0.53 \mathrm{mg} / \mathrm{mL}(\mathrm{WBW})$ to $27.57 \pm 0.17 \mathrm{mg} / \mathrm{mL}$ (WBE) (Table $8 \mathrm{a}$ ). The counterpart $\mathrm{IC}_{50}$ values for Buntan Hayata were $41.60 \pm 0.16 \mathrm{mg} / \mathrm{mL}$ (WBW) to $93.23 \pm 0.33 \mathrm{mg} / \mathrm{mL}$ (lamella) for $\alpha$-amylase, and $9.10 \pm 0.51 \mathrm{mg} / \mathrm{mL}$ (WBW) to $19.97 \pm 1.40 \mathrm{mg} / \mathrm{mL}$ (exocarp) for $\alpha$-glucosidase (Table $8 b$ ). For Peiyu, the corresponding data for $\alpha$-amylase were $28.13 \pm 0.19 \mathrm{mg} /$ $\mathrm{mL}(\mathrm{WBW})$ to $54.97 \pm 0.14 \mathrm{mg} / \mathrm{mL}$ (lamella), and those for $\alpha$-glucosidase were $2.97 \pm 0.29 \mathrm{mg} / \mathrm{mL}(\mathrm{WBW})$ to $14.97 \pm 1.95 \mathrm{mg} / \mathrm{mL}$ (mesocarp) (Table $8 \mathrm{c})$.

\subsection{Inhibitory effect on ACE}

As for the inhibition of $\mathrm{ACE}$, the $\mathrm{IC}_{50}$ values ranged from $7.24 \pm 0.65 \mathrm{mg} / \mathrm{mL}$ (WBW) to $18.72 \pm 5.19 \mathrm{mg} / \mathrm{mL}(\mathrm{WBE})$ for Buntan (Table 8a), from $5.10 \pm 0.02 \mathrm{mg} / \mathrm{mL}(\mathrm{WBW})$ to $13.10 \pm 2.62 \mathrm{mg} / \mathrm{mL}$ (lamella) for Buntan Hayata (Table 8b), and from $8.60 \pm 2.03 \mathrm{mg} / \mathrm{mL}$ (WBW) to $20.58 \pm 6.84 \mathrm{mg} / \mathrm{mL}$ (lamella) for Peiyu (Table 8c). Therefore, the WBW from the three cultivars all demonstrated extremely high activity against $\alpha$-glucosidase and ACE, implicating the necessity and reliable recovery value of these active constituents from WBW (Table 8).

\section{Discussion}

A comparison between the solvent extracts, WBW and WBE, revealed a strong antioxidative capability, pointing to the need for recovery of these invaluable polyphenolics and flavonoids from waste extracts. The pharmacological actions of protocatechuic acid have been reported to include strong in vitro and in vivo antioxidant activity (Semaming et al. 2015). However, at a higher dose ( $\geq 50 \mu \mathrm{g} / \mathrm{mL})$, a toxic effect occurred. As for the Peiyu extracts from the exocarp, a dosedependent suppression of TNF- $\alpha$ was apparent. Conversely, the extract from Peiyu mesocarp strongly upregulated the level of TNF- $\alpha$, which was entirely ineffective in suppressing the level of TNF- $\alpha$. The same phenomenon was noted for Peiyu WBW (Fig. 3c). Therefore, when grapefruits, either the whole fruit or the fruit parts, are used as antiinflammatory adjuvants, the characteristic anti-inflammatory or inflammatory bioactivity must be carefully evaluated in advance.

Recently, Ovalle-Magallanes et al. reported hypoglycemic and antihyperglycemic effects (Ovalle-Magallanes et al. 2015). In in vivo experiments using rats and mice, protocatechuic acid was demonstrated to exert antihyperglycemic bioactivity (Semaming et al. 2015). Diosmin, one of the FLVs contained in citrus, has been demonstrated to improve glucose metabolism in diabetic disorders (Hsu et al. 2017) by increasing the plasma $\beta$-endorphin-like (BER) immunoreactivity (Hsu et al. 2017) and upregulating the expression of Glut 4.

Elevated systemic DPP4 activity in the liver diminished active GLP1 levels and promoted nonalcoholic fatty liver disease and insulin resistance (Baumeier et al. 2017), a phenomenon also linked to the auto- and paracrine effects of DPP4 on hepatic insulin signaling (Baumeier et al. 2017). The administration of naringin $(40 \mathrm{mg} / \mathrm{kg}$ of b.i.d. for 10 days) inhibited the serum levels of DPP4 activity, with a 
Table 6 DPPH free radical scavenging capability of ethanolic extracts and waste blanching water from different grape fruits

\begin{tabular}{|c|c|c|c|}
\hline \multirow[t]{3}{*}{ Pomelo parts } & \multicolumn{3}{|l|}{ Solvent } \\
\hline & \multicolumn{3}{|c|}{$\mathrm{EC}_{50}$ values $(\mathrm{mg} \mathrm{TE} / \mathrm{mL})$} \\
\hline & Water & Ethanol & Methanol \\
\hline \multicolumn{4}{|l|}{ (a) Buntan } \\
\hline Exocarp & $2.48 \pm 0.01^{\mathrm{a}}$ & $2.06 \pm 0.01^{\mathrm{b}}$ & $1.62 \pm 0.01^{\mathrm{c}}$ \\
\hline Mesocarp & $2.39 \pm 0.03^{\mathrm{a}}$ & $1.44 \pm 0.03^{\mathrm{c}}$ & $1.83 \pm 0.01^{\mathrm{b}}$ \\
\hline Lamella & $3.05 \pm 0.03^{\mathrm{a}}$ & $1.15 \pm 0.01^{\mathrm{c}}$ & $1.77 \pm 0.01^{\mathrm{b}}$ \\
\hline WBW & $1.28 \pm 0.01^{\mathrm{a}}$ & $0.62 \pm 0.01^{\mathrm{c}}$ & $0.59 \pm 0.01^{\mathrm{b}}$ \\
\hline WBE & $3.42 \pm 0.01^{\mathrm{a}}$ & $2.51 \pm 0.01^{\mathrm{b}}$ & $1.90 \pm 0.01^{\mathrm{c}}$ \\
\hline \multicolumn{4}{|c|}{ (b) Buntan Hayata } \\
\hline Exocarp & $3.46 \pm 0.02^{\mathrm{a}}$ & $3.24 \pm 0.01^{\mathrm{b}}$ & $2.00 \pm 0.01^{\mathrm{c}}$ \\
\hline Mesocarp & $1.99 \pm 0.01^{\mathrm{a}}$ & $1.70 \pm 0.02^{\mathrm{b}}$ & $1.98 \pm 0.01^{\mathrm{c}}$ \\
\hline Lamella & $18.64 \pm 0.04^{\mathrm{a}}$ & $3.90 \pm 0.01^{\mathrm{b}}$ & $1.77 \pm 0.01^{\mathrm{c}}$ \\
\hline WBW & $4.04 \pm 0.03^{\mathrm{a}}$ & $1.02 \pm 0.01^{\mathrm{c}}$ & $1.30 \pm 0.01^{\mathrm{b}}$ \\
\hline WBE & $11.82 \pm 0.05^{\mathrm{a}}$ & $5.87 \pm 0.05^{\mathrm{c}}$ & $7.13 \pm 0.01^{\mathrm{b}}$ \\
\hline \multicolumn{4}{|l|}{ (c) Peiyu } \\
\hline Exocarp & $2.31 \pm 0.01^{\mathrm{a}}$ & $2.15 \pm 0.01^{\mathrm{b}}$ & $1.76 \pm 0.01^{\mathrm{c}}$ \\
\hline Mesocarp & $2.24 \pm 0.01^{\mathrm{a}}$ & $1.34 \pm 0.01^{\mathrm{b}}$ & $1.28 \pm 0.01^{\mathrm{c}}$ \\
\hline Lamella & $7.69 \pm 0.03^{\mathrm{a}}$ & $3.72 \pm 0.01^{\mathrm{b}}$ & $1.55 \pm 0.01^{\mathrm{c}}$ \\
\hline WBW & $2.02 \pm 0.01^{\mathrm{a}}$ & $1.05 \pm 0.02^{\mathrm{b}}$ & $1.05 \pm 0.01^{\mathrm{b}}$ \\
\hline WBE & $5.01 \pm 0.01^{\mathrm{a}}$ & $4.47 \pm 0.11^{\mathrm{b}}$ & $4.29 \pm 0.01^{b}$ \\
\hline
\end{tabular}

Data are expressed as mean $\pm \mathrm{SD}(n=3)$. Superscript letters in the same column indicate significant difference $(p<0.05)$

$n . d$. not detected, WBW waste blanching water, WBE waste blanching water from exocarps

random glucose concentration and concomitant increase in insulin levels observed in Wistar albino rats (Parmar et al. 2012). DPP4 inhibition offers a novel potential therapeutic approach for T2DM, as monotherapy and adjuvant therapy to other oral agents (Matteucci and Giampietro 2009). The use of a DPP4 inhibitor called vildagliptin was approved in Europe and Latin America combined with metformin, sulfonylurea, or thiazolidinedione (Dicker 2011). Two other DPP4 inhibitors are also available (linagliptin and alogliptin) (Dicker 2011). DPP4 degrades incretin peptides (e.g., GLP1) and is widely known for its regulatory effect on glucose metabolism (Drucker and Nauck 2006).

By contrast, in HepG2 cells, caffeic acid and coumaric acid exhibited Glut4-upregulating bioactivity, whereas coumaric acid, which downregulates DDP4 (Fig. 6b, c), demonstrated cell specificity against various polyphenolics.

Alternately, hesperidin and naringin supplementation potentially ameliorated the status of hyperglycemia and alleviated the lipid profile, serum adiponectin, and resistin
Table 7 Trolox equivalent antioxidant capability of ethanolic extracts and waste blanching water from different grape fruits

\begin{tabular}{|c|c|c|c|}
\hline \multirow[t]{3}{*}{ Pomelo parts } & \multicolumn{3}{|l|}{ Solvent } \\
\hline & \multicolumn{3}{|c|}{$\mathrm{EC}_{50}$ values $(\mathrm{mg} \mathrm{TE} / \mathrm{mL})$} \\
\hline & Water & Ethanol & Methanol \\
\hline \multicolumn{4}{|l|}{ (a) Buntan } \\
\hline Exocarp & $13.88 \pm 0.07^{\mathrm{a}}$ & $8.14 \pm 0.22^{b}$ & $3.98 \pm 0.06^{\mathrm{c}}$ \\
\hline Mesocarp & $36.54 \pm 2.28^{\mathrm{a}}$ & $23.86 \pm 0.99^{b}$ & $15.61 \pm 0.11^{\mathrm{c}}$ \\
\hline Lamella & $17.30 \pm 0.06^{\mathrm{b}}$ & $24.26 \pm 0.48^{\mathrm{a}}$ & $10.01 \pm 0.03^{\mathrm{c}}$ \\
\hline WBW & $3.33 \pm 0.02^{\mathrm{a}}$ & $1.74 \pm 0.16^{\mathrm{c}}$ & $2.10 \pm 0.01^{b}$ \\
\hline WBE & $8.06 \pm 0.01^{\mathrm{a}}$ & $2.30 \pm 0.00^{c}$ & $2.40 \pm 0.05^{\mathrm{b}}$ \\
\hline \multicolumn{4}{|c|}{ (b) Buntan Hayata } \\
\hline Exocarp & $10.19 \pm 0.26^{\mathrm{a}}$ & $5.79 \pm 0.02^{b}$ & $4.81 \pm 0.18^{\mathrm{c}}$ \\
\hline Mesocarp & $24.76 \pm 0.22^{\mathrm{a}}$ & $19.67 \pm 0.41^{\mathrm{b}}$ & $12.27 \pm 0.15^{\mathrm{c}}$ \\
\hline Lamella & $111.28 \pm 11.19^{\mathrm{a}}$ & $22.32 \pm 0.80^{\mathrm{b}}$ & $9.29 \pm 0.13^{b}$ \\
\hline WBW & $16.41 \pm 0.11^{\mathrm{a}}$ & $4.98 \pm 0.10^{\mathrm{b}}$ & $2.07 \pm 0.04^{\mathrm{c}}$ \\
\hline WBE & $74.13 \pm 1.76^{a}$ & $23.19 \pm 1.26^{\mathrm{b}}$ & $7.97 \pm 0.06^{\mathrm{c}}$ \\
\hline \multicolumn{4}{|l|}{ (c) Peiyu } \\
\hline Exocarp & $16.20 \pm 0.07^{\mathrm{a}}$ & $14.37 \pm 0.37^{\mathrm{b}}$ & $4.10 \pm 0.02^{\mathrm{c}}$ \\
\hline Mesocarp & $42.47 \pm 0.92^{\mathrm{a}}$ & $21.60 \pm 0.12^{\mathrm{b}}$ & $8.46 \pm 0.15^{\mathrm{c}}$ \\
\hline Lamella & $35.31 \pm 0.17^{\mathrm{a}}$ & $17.55 \pm 0.48^{\mathrm{b}}$ & $4.33 \pm 0.13^{\mathrm{c}}$ \\
\hline WBW & $15.97 \pm 0.16^{\mathrm{a}}$ & $3.88 \pm 0.01^{\mathrm{b}}$ & $2.07 \pm 0.04^{\mathrm{c}}$ \\
\hline WBE & $21.95 \pm 0.02^{\mathrm{a}}$ & $17.84 \pm 0.57^{b}$ & $6.46 \pm 0.06^{\mathrm{c}}$ \\
\hline
\end{tabular}

Data are expressed as mean \pm SD $(n=3)$. Superscript letters in the same column indicate significant difference $(p<0.05)$

$n . d$. not detected, WBW waste blanching water, WBE waste blanching water from exocarps

levels, which helped alleviate the DM syndrome (Osama et al. 2012). Supposedly, when consuming whole fruit wastes, the effect of caffeic acid is abolished or balanced by the other coexisting constituents. Evidently, when taking partially purified or single pure compounds as part of a cotherapy for the treatment of DM, such an effect should be considered in advance.

Moreover, the waste extracts and WBW were more effective against the activity of $\alpha$-glucosidase. Hesperidin and naringin have potential antihyperglycemic and antidyslipidemic effects (Osama et al. 2012). Previously, Shen et al. demonstrated that Citrus flavonoids significantly inhibited amylase-catalyzed starch digestion (Shen et al. 2012); naringin and neohesperidin mainly inhibited amylose digestion, whereas hesperidin and nobiletin inhibited both amylose and amylopectin digestion (Shen et al. 2012). CFA derivatives inhibited $\alpha$-amylase and $\alpha$-glucosidase in a concentrationdependent manner (Chiou et al. 2017). The following mechanisms of Citrus flavonoids in preventing the progression of 
Fig. 2 The viability of Raw 264.7 cells affected by the ethanolic extracts of different parts and the waste blanching water. a Buntan (BTN), b Buntan Hayata (BTNH), and $\mathbf{c}$ Peiyu (PY). ECP: exocarp. MCP: mesocarp. WBW: Waste blanching water. Data are expressed as mean $\pm \operatorname{SD}(n=3)$. Superscript letters in the same column indicate significant difference $(p<0.05)$

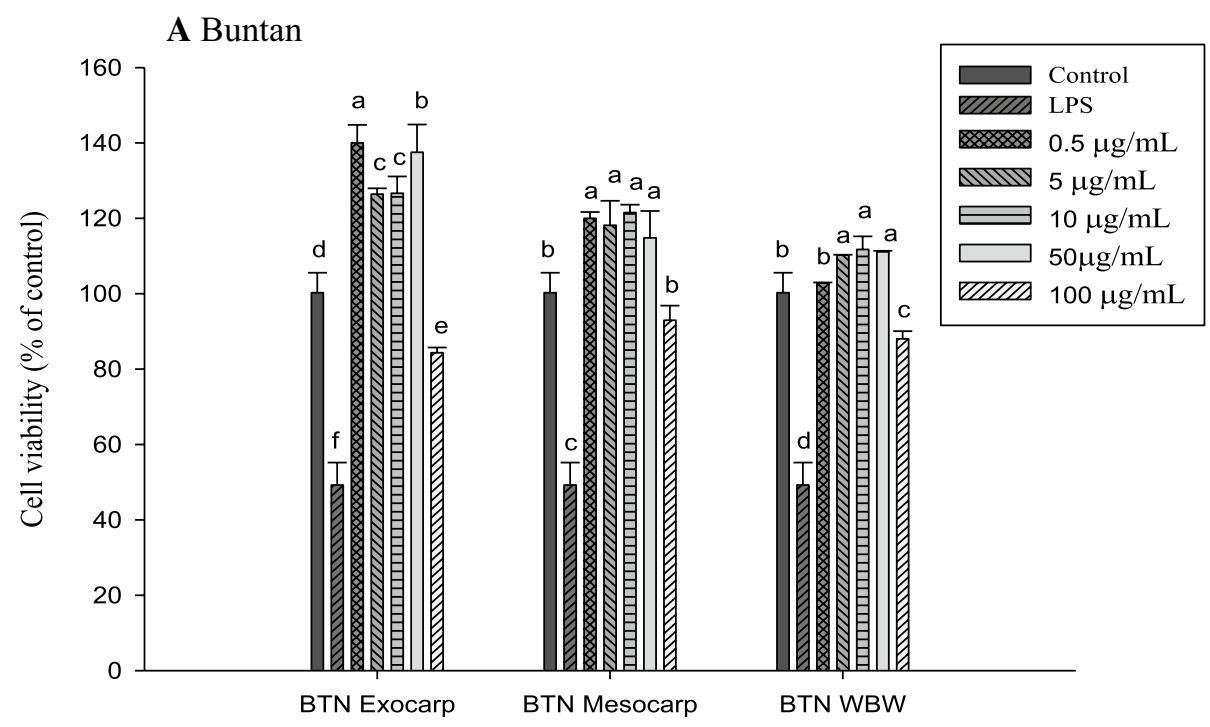

B Buntan Hayata

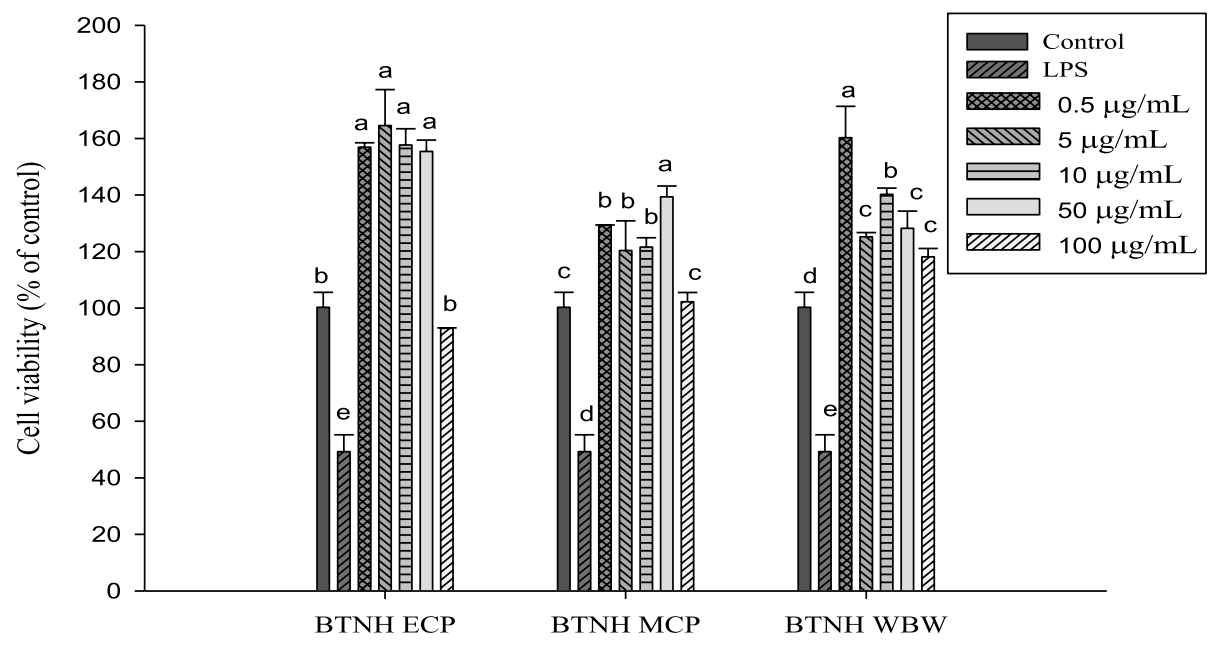

C Peiyu.

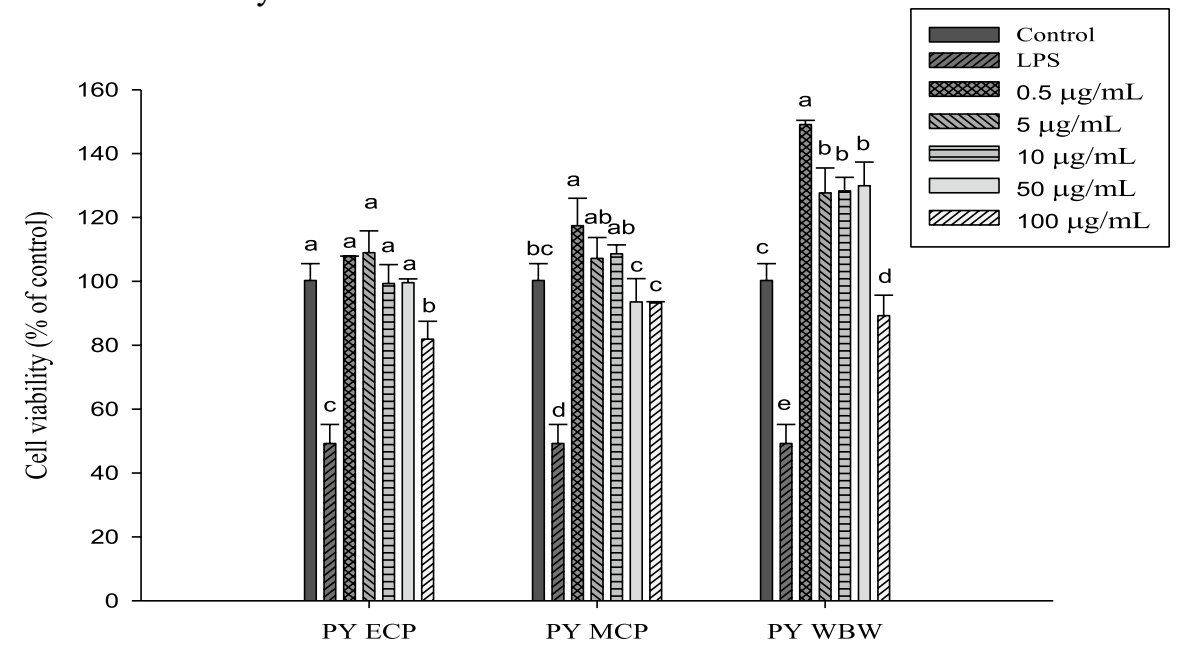



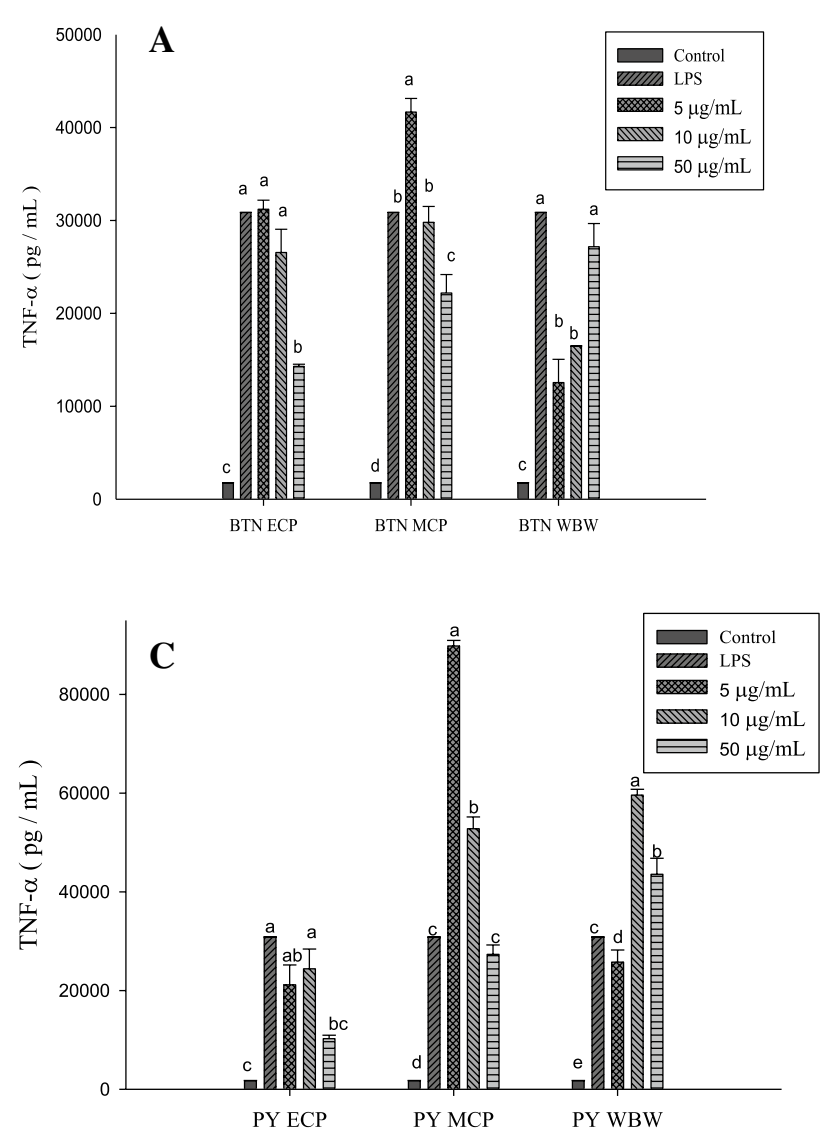

Fig. 3 Effect of the ethanolic extracts of different grapefruit waste parts and the waste blanching water on the expression of TNF- $\alpha$ in Raw264.7 cells. a Buntan (BTN), b Buntan Hayata (BTNH), c Peiyu (PY), d Comparison of the effects in Raw264.7 cells when using

hyperglycemia have been proposed. Citrus flavonoids bind to starch, resulting in an increased hepatic glycolysis and glycogen concentration and a lower hepatic gluconeogenesis (Shen et al. 2012). Furthermore, glucose consumption, glycogen concentration, and glucokinase activity were significantly increased, and glucose-6-phosphatase activity was markedly decreased by Citrus FLVs (Shen et al. 2012).
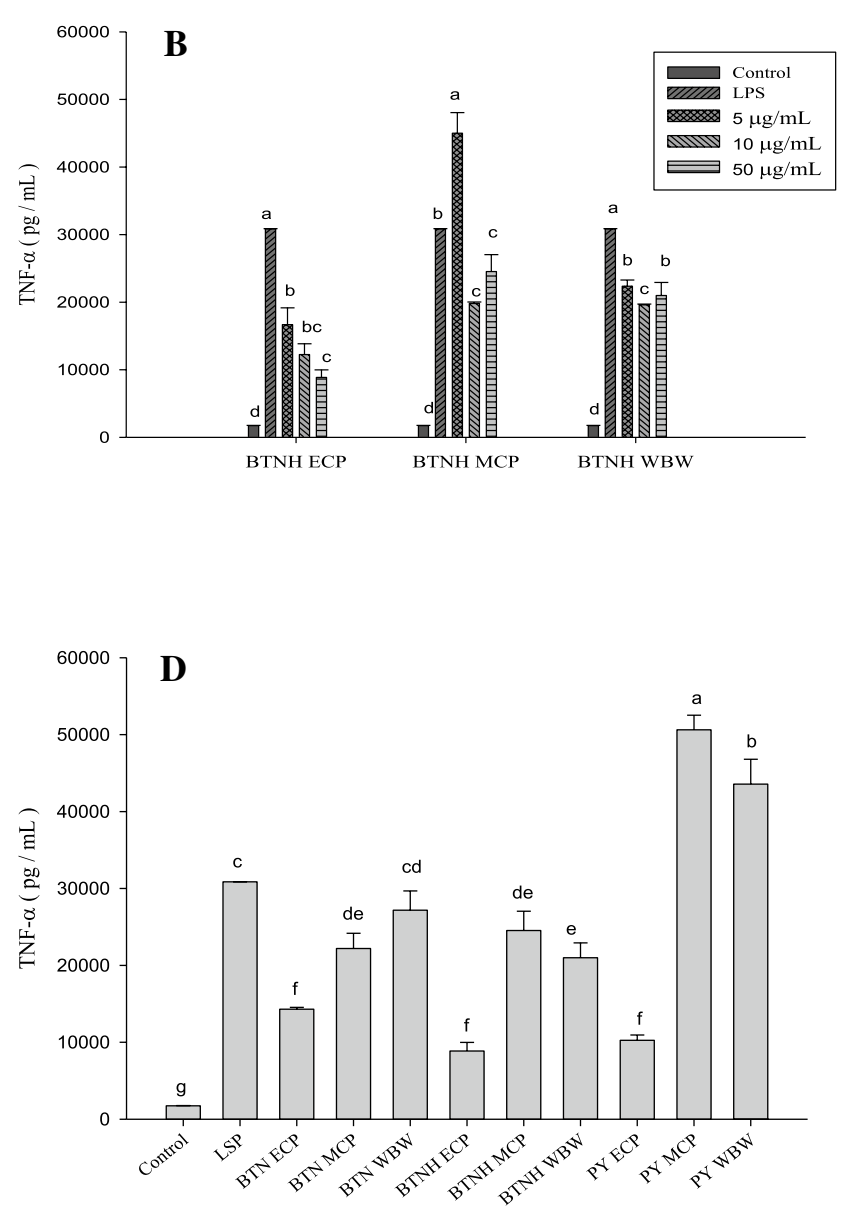

$50 \mu \mathrm{g} / \mathrm{mL}$. ECP: exocarp. MCP: mesocarp. WBW: Waste blanching water. Data are expressed as mean $\pm \operatorname{SD}(n=3)$. Superscript letters in the same column indicate significant difference $(p<0.05)$

In addition, caffeic acid derivatives have been demonstrated to dose dependently exert a high inhibitory effect on ACE; its $\mathrm{IC}_{50}$ values ranged from $0.11-0.14 \mathrm{mg} / \mathrm{mL}$ (Chiou et al. 2017), suggesting that GW is potentially antihyperglycemic and antihypertensive, and the natural grapefruit extracts would be safer and healthier in this respect. In summary, recycling pomelo fruit wastes offers many benefits, 
Fig. 4 The viability of RIN$\mathrm{m} 5 \mathrm{~F}$ cells affected by the ethanolic extracts from different parts and the waste blanching water. a Buntan (BTN), b Bun$\tan$ Hayata (BTNH), c Peiyu (PY). ECP: exocarp. MCP: mesocarp. WBW: Waste blanching water. Data are expressed as mean $\pm \mathrm{SD}(n=3)$. Superscript letters in the same column indicate significant difference $(p<0.05)$
A Buntan
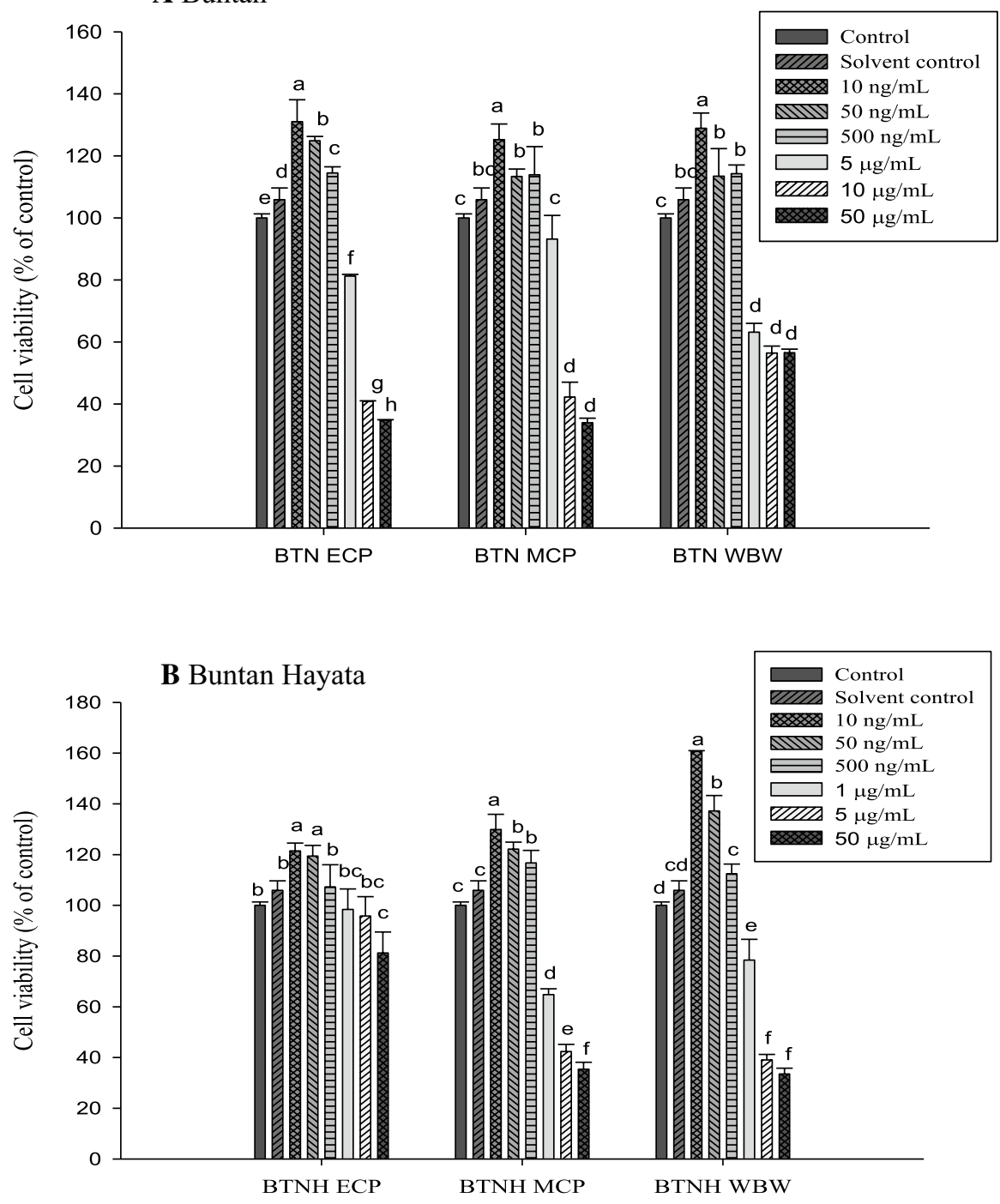

C Peiyu.

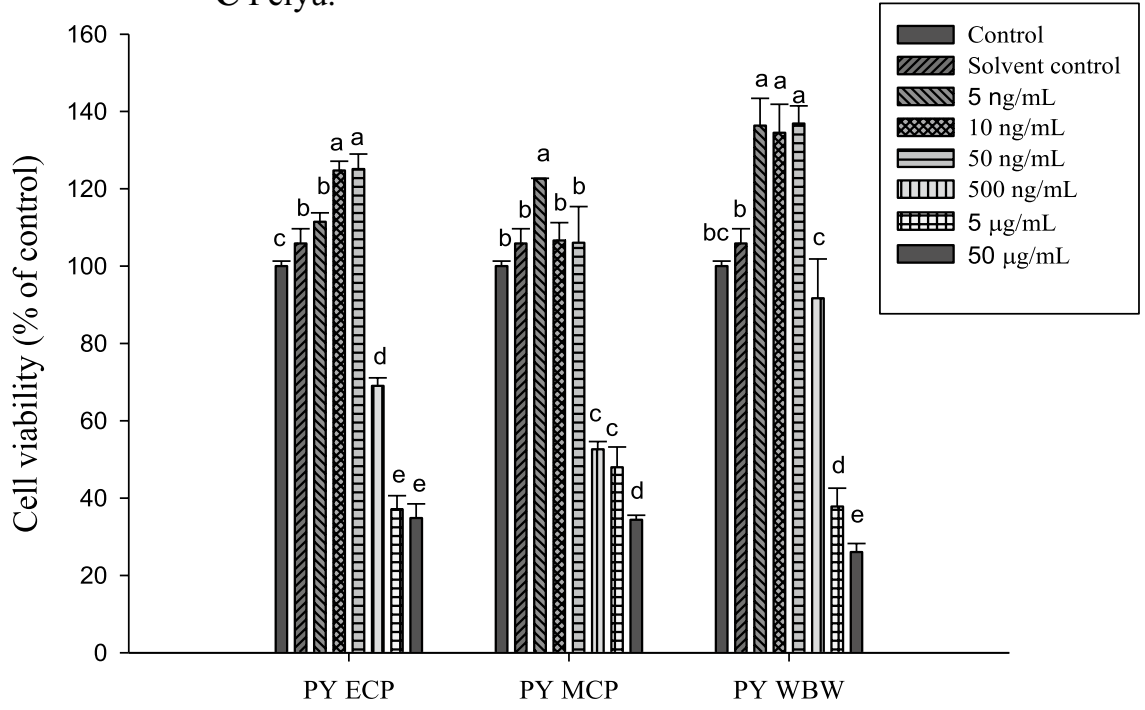


Fig. 5 Effect of the ethanolic extracts of different parts and the waste blanching water on the insulin secretion in RINm5F cells. a Buntan (BTN), b Buntan Hayata (BTNH), c Peiyu (PY). ECP exocarp, MCP mesocarp, WBW waste blanching water. Data are expressed as mean $\pm \mathrm{SD}(n=3)$. Superscript letters in the same column indicate significant difference $(p<0.05)$
A Buntan

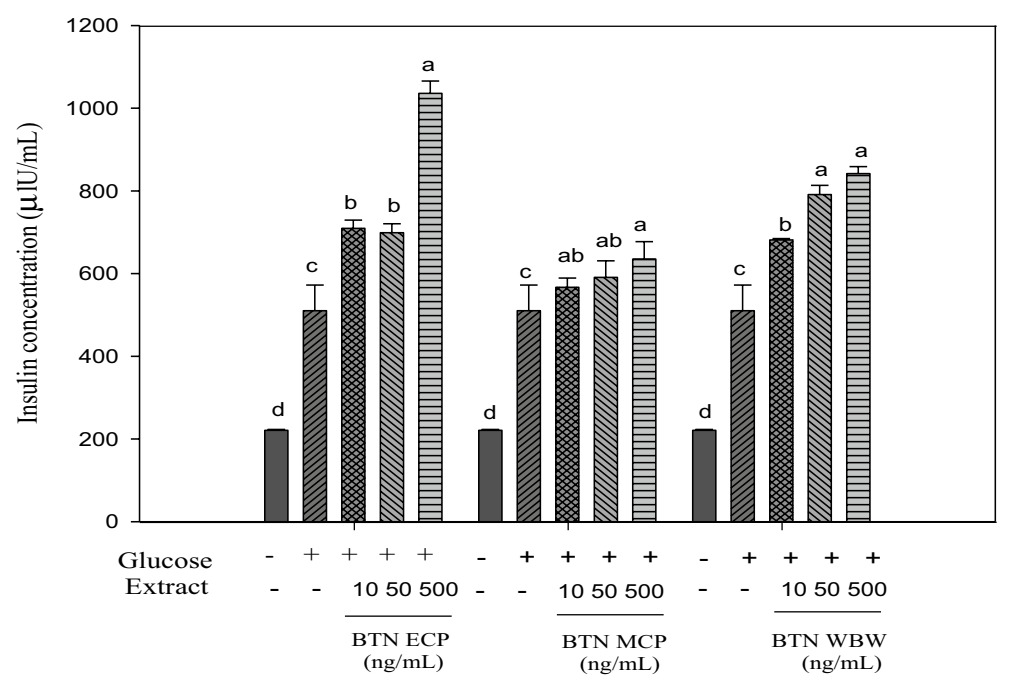

B Buntan Hayata

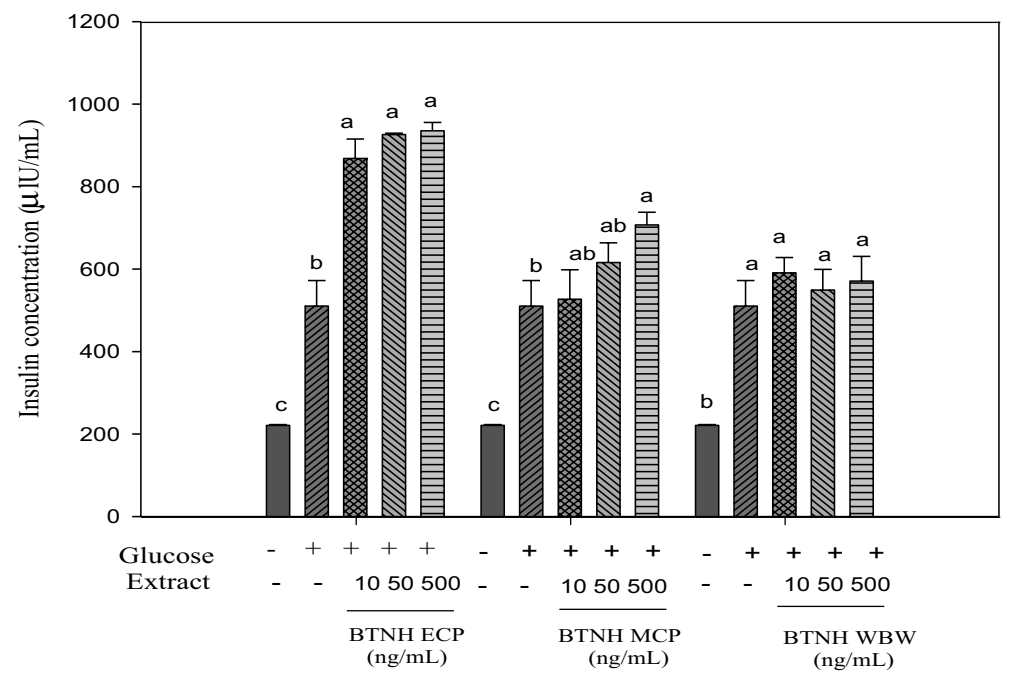

C Peiyu.

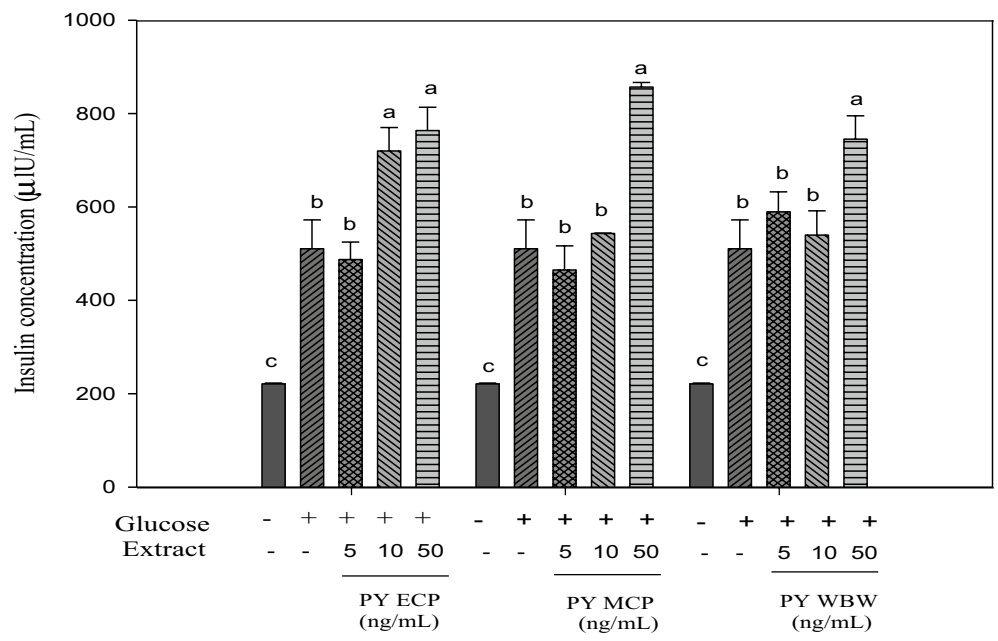


Fig. 6 Effect of some representative constituents from grape fruits in the HepG2 cells. a Cell viability, b glut 4 expression, and $\mathbf{c}$ DPP4 level. Each group was treated with $100 \mu \mathrm{M}$ of the compounds as indicated. Abbreviations: $\mathrm{C}$ : the control. PCTA: Protocatechuic acid. CFA: Caffeic acid. CMA: Coumaric acid. DSM: Diosmin. NA: naringin. HPN: Hesperidin. Data are expressed as mean $\pm \mathrm{SD}(n=3)$. Superscript letters in the same column indicate significant difference $(p<0.05)$

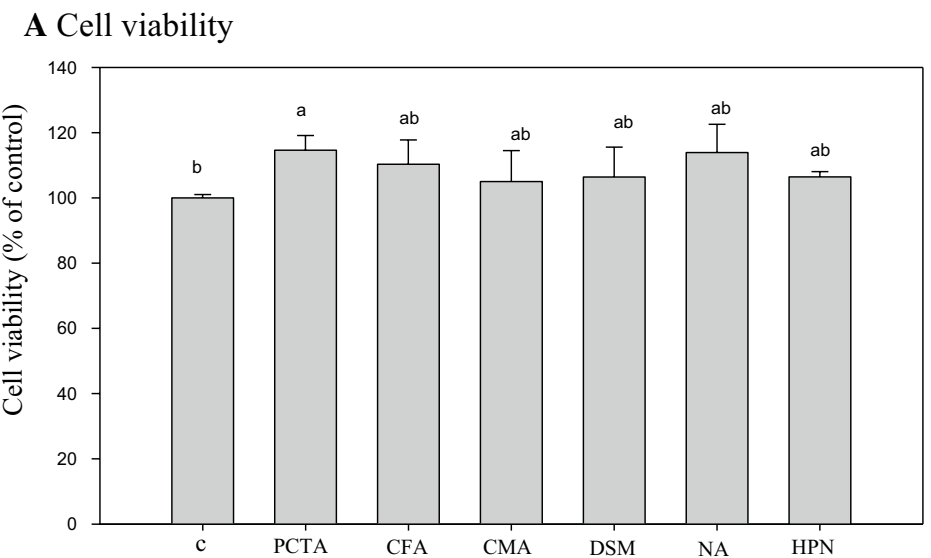

\section{B Glut 4 expression}

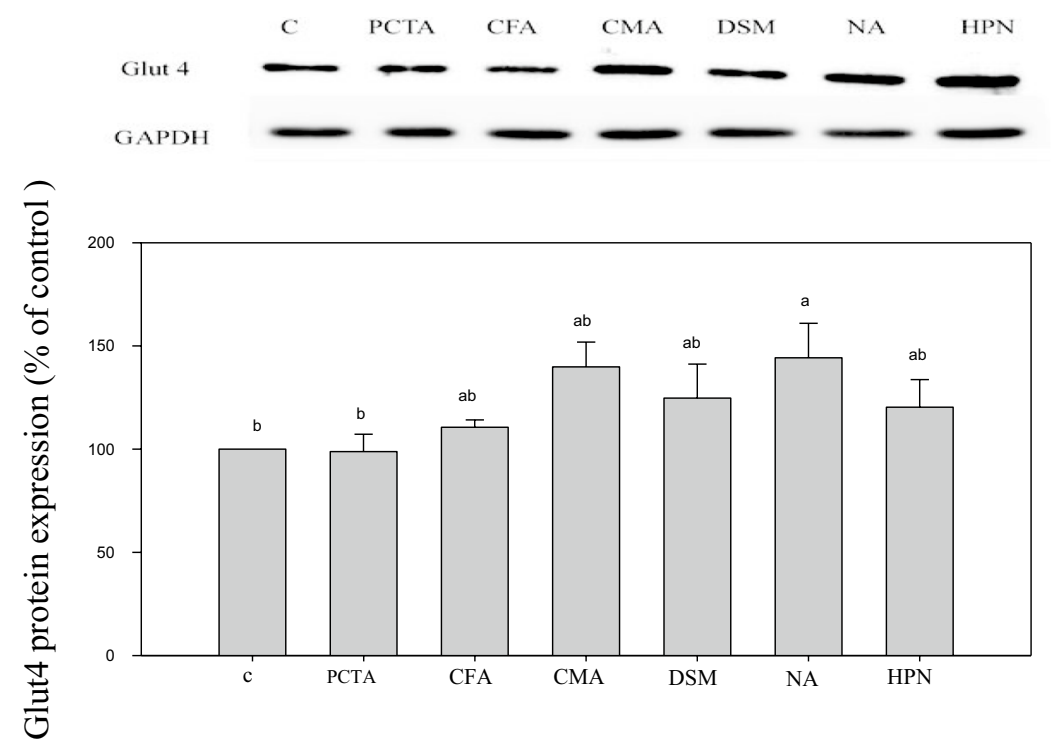

\section{DPP4}
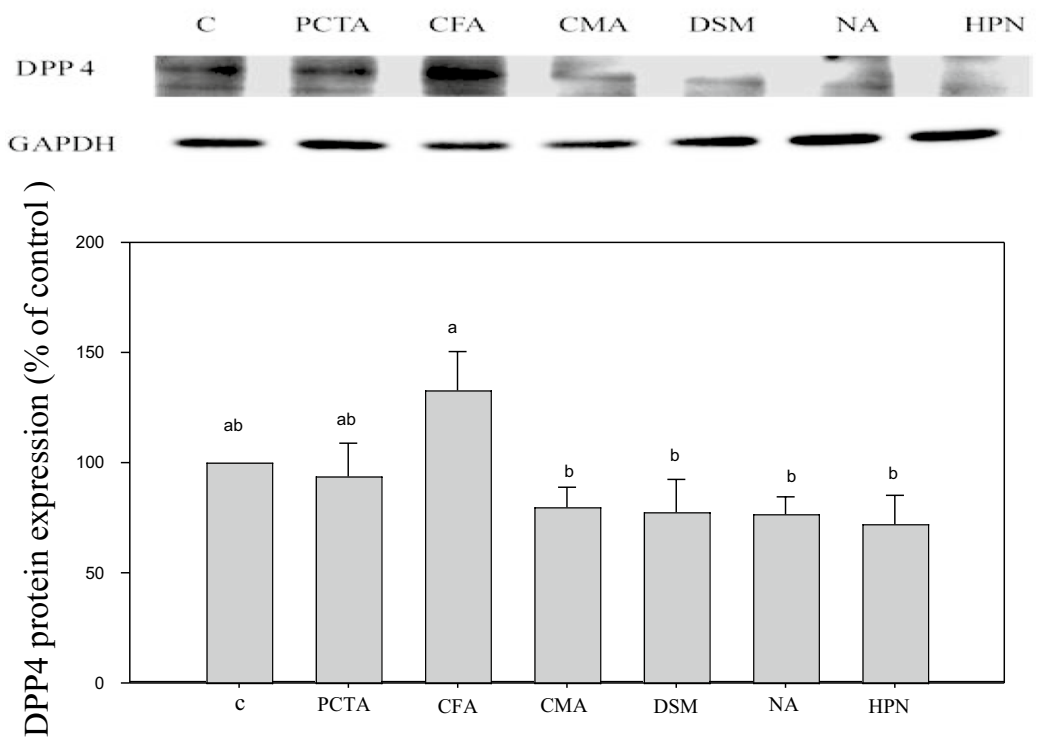
Fig. 7 Intracellular insulin level in Rin-m5F cells affected by some representative constituents from grape fruits. $C$ the control, PCTA protocatechuic acid, CFA caffeic acid, CMA coumaric acid, DSM diosmin, NA naringin, HPN hesperidin. Data are expressed as mean $\pm \mathrm{SD}(n=3)$. Superscript letters in the same column indicate significant difference $(p<0.05)$

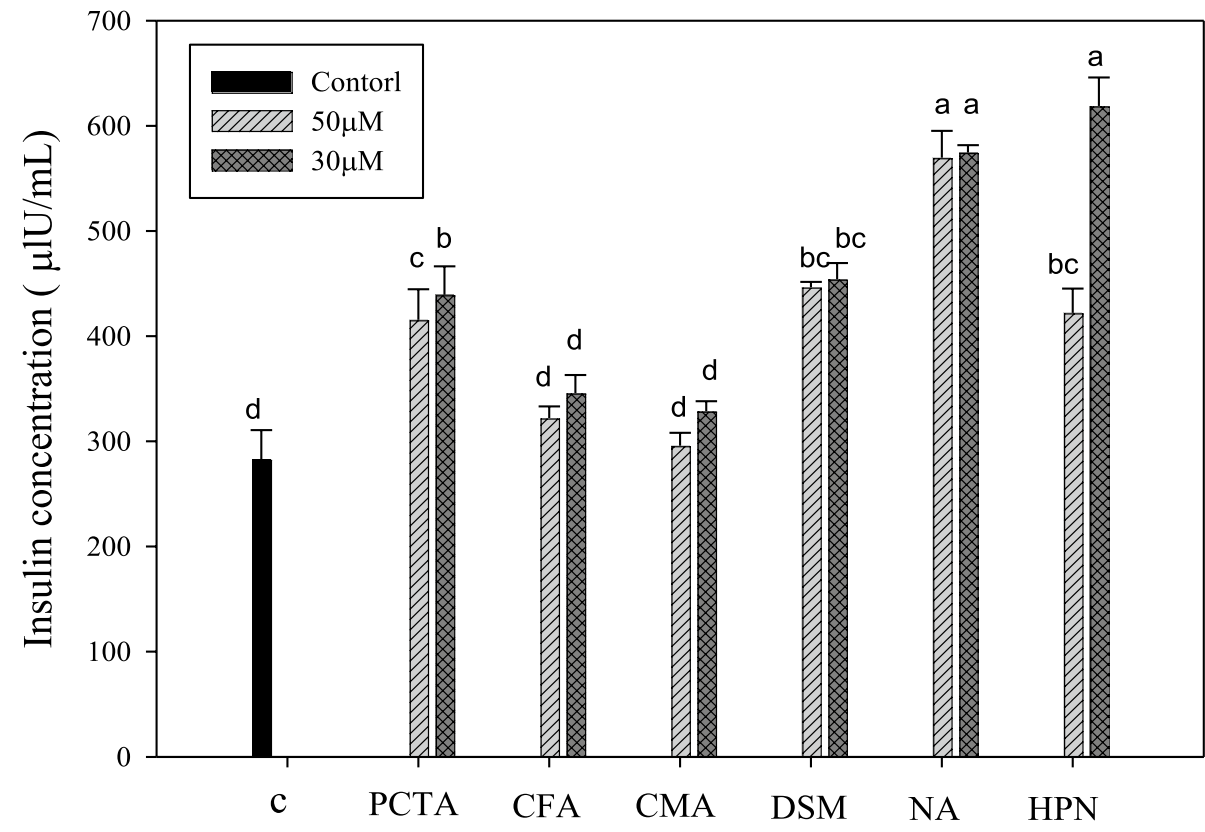

and it would be advantageous to set up a facility to separate the waste of pomelo fruits into different parts and treated them as mentioned in this study to reclaim the many valuable compounds. This would be both economically and environmentally beneficial.

\section{Conclusion}

Polyphenolics and flavonoids are key bioactive natural products and functional foods. The processing of grapefruits usually produces considerable amounts of wastes, including exocarps, mesocarps, lamellae, WBW, and WBW from exocarps (denoted as GW), representing the loss of a considerable amount of polyphenolics and flavonoids. The main constituents of polyphenolics include gallic acid, protocatechuic acid, chlorogenic acid, caffeic acid, ferulic acid, and coumaric acid. Flavonoids consist of naringin, hesperidin, diosmin, hesperetin, nobiletin, and tangeretin (denoted as GW constituents, GWCs). These compounds have been reported to be relatively active antioxidants, anti-inflammatories, antihypertensives, and antihyperglycemics. GWCs exhibit promising anti-inflammatory bioactivity in the Raw264.7 cell model. They upregulate the Glut4 in HepG2 cells as well as the insulin secretion capability and intracellular insulin concentration levels in RIN-m5F cells, and they downregulate DPP4 in HepG2 cells. In addition, in vitro, the ethanolic extracts of GW inhibit the pancreatic $\alpha$-amylase and $\alpha$-glucosidase. In conclusion, because of their safe administration, low cost, facility of access, ecofriendly nature, and nutraceutical and medical applications, such wastes are worth reclaiming.
Table 8 Inhibitory effect on $\alpha$-amylase, $\alpha$-glucosidase, and ACE by the ethanolic extracts from different parts of various grape fruits

\begin{tabular}{llrr}
\hline Pomelo parts & \multicolumn{3}{l}{$\mathrm{IC}_{50}$ value $(\mathrm{mg} / \mathrm{mL})$} \\
\cline { 2 - 4 } & $\alpha$-Amylase & $\alpha$-Glucosidase & \multicolumn{1}{c}{ ACE } \\
\hline (a) Buntan & & & \\
Exocarp & $51.10 \pm 0.04^{\mathrm{b}}$ & $12.11 \pm 0.18^{\mathrm{d}}$ & $12.70 \pm 2.86^{\mathrm{ab}}$ \\
Mesocarp & $36.78 \pm 0.48^{\mathrm{c}}$ & $17.07 \pm 0.04^{\mathrm{b}}$ & $7.44 \pm 2.08^{\mathrm{b}}$ \\
Lamella & $60.19 \pm 5.07^{\mathrm{a}}$ & $10.24 \pm 0.50^{\mathrm{c}}$ & $9.47 \pm 1.58^{\mathrm{b}}$ \\
WBW & $27.96 \pm 0.03^{\mathrm{d}}$ & $1.80 \pm 0.53^{\mathrm{e}}$ & $7.24 \pm 0.65^{\mathrm{b}}$ \\
WBE & $60.45 \pm 0.72^{\mathrm{a}}$ & $27.57 \pm 0.17^{\mathrm{a}}$ & $18.72 \pm 5.19^{\mathrm{a}}$
\end{tabular}

(b) Buntan Hayata

$\begin{array}{lccc}\text { Exocarp } & 44.49 \pm 0.19^{\mathrm{d}} & 19.97 \pm 1.40^{\mathrm{a}} & 7.58 \pm 1.95^{\mathrm{bc}} \\ \text { Mesocarp } & 56.02 \pm 0.96^{\mathrm{b}} & 13.19 \pm 0.48^{\mathrm{b}} & 10.21 \pm 2.70^{\mathrm{ab}} \\ \text { Lamella } & 93.23 \pm 0.33^{\mathrm{a}} & 12.19 \pm 0.73^{\mathrm{bc}} & 13.10 \pm 2.62^{\mathrm{a}} \\ \text { WBW } & 41.60 \pm 0.16^{\mathrm{e}} & 9.10 \pm 0.51^{\mathrm{c}} & 5.10 \pm 0.02^{\mathrm{c}} \\ \text { WBE } & 52.58 \pm 0.06^{\mathrm{c}} & 13.05 \pm 2.44 \mathrm{~b}^{\mathrm{c}} & 7.08 \pm 2.09^{\mathrm{bc}}\end{array}$

(c) Peiyu

Exocarp

$$
35.75 \pm 0.42^{\mathrm{b}}
$$

$6.70 \pm 0.46^{\mathrm{b}}$

$8.83 \pm 1.56^{\mathrm{b}}$

Mesocarp

$28.71 \pm 0.20^{\mathrm{d}}$

$14.97 \pm 1.95^{\mathrm{a}}$

$14.60 \pm 3.08^{\mathrm{ab}}$

Lamella

$54.97 \pm 0.14^{\mathrm{a}}$

WBW

$28.13 \pm 0.19^{\mathrm{e}}$

$3.75 \pm 0.14^{\mathrm{c}}$

$20.58 \pm 6.84^{\mathrm{a}}$

WBE

$29.57 \pm 0.06^{c}$

$2.97 \pm 0.29^{\mathrm{c}}$

$8.60 \pm 2.03^{\mathrm{b}}$

Data are expressed as mean $\pm \mathrm{SD}(n=3)$. Superscript letters in the same column indicate significant difference $(p<0.05)$ n.d. not detected, WBW waste blanching water, WBE waste blanching water from exocarps

The use of these rich bioactive citrus residues provides efficient, inexpensive, and environmentally friendly nutraceuticals. 
Acknowledgements This manuscript was edited by Wallace Academic Editing and this work was funded by the Ministry of Science and Technology MOST 109-2320-B-038-059- and Taipei Medical UniversityShuang Ho Hospital 109TMU-SHH-12.

Author contributions LYL, KCC and RYP contributed to this work by designing the study, obtaining data, performing the statistical analysis, writing the manuscript and interpreted the data. LYL and CYH participated in the conception and design of the study and acquisition of data. RYP and KCC participated in the conception and design of the study and interpretation of the data and reviewed and edited the manuscript. All authors read and approved the final manuscript.

Data availability All data generated or analysed during this study are included in this published article.

\section{Compliance with ethical standards}

Conflict of interest The authors declare that they have no competing interests.

Open Access This article is licensed under a Creative Commons Attribution 4.0 International License, which permits use, sharing, adaptation, distribution and reproduction in any medium or format, as long as you give appropriate credit to the original author(s) and the source, provide a link to the Creative Commons licence, and indicate if changes were made. The images or other third party material in this article are included in the article's Creative Commons licence, unless indicated otherwise in a credit line to the material. If material is not included in the article's Creative Commons licence and your intended use is not permitted by statutory regulation or exceeds the permitted use, you will need to obtain permission directly from the copyright holder. To view a copy of this licence, visit http://creativecommons.org/licenses/by/4.0/.

\section{References}

Baumeier C, Schlüter L, Saussenthaler S, Laeger T, Rödiger M, Alaze SA, Fritsche L, Häring H-U, Stefan N, Fritsche A, Schwenk RW, Schürmann A (2017) Elevated hepatic DPP4 activity promotes insulin resistance and non-alcoholic fatty liver disease. Mol Metabol 6:1254-1263

Carey RM (2015) The intrarenal renin-angiotensin system in hypertension. Adv Chronic Kidney Dis 22(3):204-210

Chiou SY, Sung JM, Huang P-W, Lin SD (2017) Antioxidant, antidiabetic, and antihypertensive properties of Echinacea purpurea flower extract and caffeic acid derivatives using in vitro models. J Med Food 20:171-179

Deacon CF (2011) Dipeptidyl peptidase-4 inhibitors in the treatment of type 2 diabetes: a comparative review. Diabetes Obes Metab $13: 7-18$

Dicker D (2011) DPP-4 Inhibitors. Impact on glycemic control and cardiovascular risk factors. Diabetes Care 34:S276-S278

Drucker DJ, Nauck M (2006) The incretin system: glucagon-like peptide- 1 receptor agonists and dipeptidyl peptidase- 4 inhibitors in type 2 diabetes. Lancet 368:1696-1705

Du K, Murakami S, Sun Y, Kilpatrick CL, Luscher B (2017) DHHC7 palmitoylates glucose transporter 4 (Glut4) and regulates Glut4 membrane translocation. J. Biol Chem 292:2979-2991

Erez G, Tirosh A, Rudich A, Meiner V, Schwarzfuchs D, Sharon N, Shpitzen S, Blüher M, Stumvoll M, Thiery J, Fiedler GM, Friedlander Y, Leiterstdorf E, Shai I (2011) Phenotypic and genetic variation in leptin as determinants of weight regain. Int $\mathrm{J}$ Obes (Lond) 35:785-792

Fayek NM, El-Shazly AH, Abdel-Monem AR, Moussa MY, Abd-Elwahab SM, El-Tanbouly ND (2017) Comparative study of the hypocholesterolemic, antidiabetic effects of four agro-waste Citrus peels cultivars and their HPLC standardization. Rev Brasil Farmacogn 27:488-494

Fyhrquist F, Metsärinne K, Tikkanen I (1995) Role of angiotensin II in blood pressure regulation and in the pathophysiology of cardiovascular disorders. J Hum Hypertens 5:S19-S24

Hsu CC, Lin MH, Cheng JT, Wu MC (2017) Antihyperglycaemic action of diosmin, a citrus flavonoid, is induced through endogenous $\beta$-endorphin in type I-like diabetic rats. Clin Exp Pharmacol Physiol 44:549-555

Huang P, Altshuller YM, Hou JC, Pessin JE, Frohman MA (2005) Insulin-stimulated plasma membrane fusion of Glut 4 glucose transporter-containing vesicles is regulated by phospholipase D1. Mol Biol Cell 16:2614-2623

IDF (International Diabetes Federation): cohort report (2017)

Iqbal S, ur Rehman N, Kortz U, Iqbal J (2013) Development of a fast and efficient CE enzyme assay for the characterization and inhibition studies of $\alpha$-glucosidase inhibitors. J Sep Sci 36:3463-3658

Li L, Tsao R, Yang R, Liu C, Zhu H, Young JC (2006) Polyphenolic profiles and antioxidant activities of heartnut (Juglans ailanthifolia Var. cordiformis) and Persian walnut (Juglans regia L.). J Agric Food Chem 54:8033-8040

Lin LY, Peng CC, Yang YL, Peng RY (2008) Optimization of bioactive compounds in buckwheat sprouts and their effect on blood cholesterol in hamsters. J Agric Food Chem 56:1216-1223

Lü ZF, Zhang Z, Wu H-M, Zhou Z-Q, Yu J (2016) Phenolic composition and antioxidant capacities of chinese local pummelo cultivars' peel. Horticult Plant J 2:133-140

Matteucci E, Giampietro O (2009) Dipeptidyl peptidase-4 (CD26): knowing the function before inhibiting the enzyme. Curr Med Chem 16:2943-2951

Miller NJ, Rice-Evans CA, Davies MJ, Gopinathan V, Milner A (1993) A novel method for measuring antioxidant capacity and its application to monitoring the antioxidant status in premature neonates. Clin Sci 84:407-412

Nicholson G, Hall GM (2011) Diabetes mellitus: new drugs for a new epidemic. Br J Anaesth 107:65-73

Oboh G, Ogunsuyi OB, Ogunbadejo MD, Adefegha SA (2016) Influence of gallic acid on a-amylase and a-glucosidase inhibitory properties of acarbose. J Food Drug Anal 24:627-634

Ovalle-Magallanes B, Medina-Campos ON, Pedraza-Chaverri J, Mata R (2015) Hypoglycemic and antihyperglycemic effects of phytopreparations and limonoids from Swietenia humilis. Phytochem 110:111-119

Osama MA, Ayman MM, Adel A-M, Mohamed BA (2012) Antidiabetic effects of heperidin and naringin in type 2 diabetic rats. Diabetol Croat 41:53-67

Parmar HS, Jain P, Chauhan DS, Bhinchar MK, Munjal V, Yusuf M, Choube K, Tawani A, Tiwari V, Manivannan E, Kuma A (2012) DPP-IV inhibitory potential of naringin: An in silico, in vitro and in vivo study. Diabetes Res Clin Pract 97(1):105-111

Pinto MD, Kwon YI, Apostolidis E, Lajolo FM, Genovese MI, Shetty K (2010) Evaluation of red currants (Ribes rubrum L), black currants (Ribes nigrum L.), red and green gooseberries (Ribes uva-crispa) for potential management of type 2 diabetes and hypertension using in vitro models. J Food Biochem 34:639-660

Sato M, Ramarathnam N, Suzuki Y, Ohkubo T, Takeuchi M, Ochi H (1996) Varietal differences in the phenolic content and superoxide radical scavenging potential of wines from different sources. J Agric Food Chem 44:37-41

Schnell O, Weng J, Sheu WH-H, Watada H, Kalra S, Soegondo S, Yamamoto N, Rathod R, Zhang C, Grzeszczak W (2016) Acarbose 
reduces body weight irrespective of glycemic control in patients with diabetes: results of a worldwide, non-interventional, observational study data pool. J Diabetes Complic 30:628-637

Segura Campos MR, Peralta GF, Chel GL, Betancur AD (2013) Angiotensin I-converting enzyme inhibitory peptides of chia (Salvia hispanica) produced by enzymatic hydrolysis. Int J Food Sci 2013:158482

Semaming Y, Pannengpetch P, Chattipakorn SC, Chattipakorn N (2015) Pharmacological properties of protocatechuic acid and its potential roles as complementary medicine. Hindawi Publishing Corporation

Shen W, Xu Y, Lu YH (2012) Inhibitory effects of Citrus flavonoids on starch digestion and antihyperglycemic effects in HepG2 cells. J Agric Food Chem 60:9609-9619. https://doi.org/10.1021/jf3032556

Sheng Z, Dai H, Pan S, Wang H, Hu Y, Ma W (2014) Isolation and characterization of an $\alpha$-glucosidase inhibitor from Musa spp. (Baxijiao) flowers. Molecules 19:10563-10573

Shukor NA, Van Camp J, Gonzales GB, Staljanssens D, Struijs K, Zotti MJ, Raes K, Smagghe G (2013) Angiotensin-converting enzyme inhibitory effects by plant phenolic compounds: a study of structure activity relationships. J Agric Food Chem 61:11832-11839

Sun C, Chen K, Chen Y, Chen Q (2005) Contents and antioxidant capacity of limonin and nomilin in different tissues of citrus fruit of four cultivars during fruit growth and maturation. Food Chem 93:599-605

Tsai HS, Huang LJ, Lai YH, Chang JC, Lee RS, Chiou RYY (2007) Solvent effects and HPLC analysis of soybeans isoflavones and variations of isoflavone compositions as affected by crop season. J Agric Food Chem 55:7712-7715

Zilleßen P, Celner J, Kretschmann A, Pfeifer A, Racké K, Mayer P (2016) Metabolic role of dipeptidyl peptidase 4 (DPP4) in primary human (pre)adipocytes. Sci Rep 6:23074. https://doi.org/10.1038/ srep23074

Publisher's Note Springer Nature remains neutral with regard to jurisdictional claims in published maps and institutional affiliations. 